\title{
Alternative and Unconventional Feeds in Dairy Diets and Their Effect on Fatty Acid Profile and Health Properties of Milk Fat
}

\author{
Sylvie Hadrová ${ }^{1}$, Kateřina Sedláková ${ }^{2}$, Ludmila Kří̌̌ová ${ }^{2, * \mathbb{D}}$ and Svetlana Malyugina ${ }^{1}$ (D) \\ 1 Agrovýzkum Rapotín Ltd., 78813 Vikýřovice, Czech Republic; sylvie.hadrova@vuchs.cz (S.H.); \\ svetlana.malyugina@vuchs.cz (S.M.) \\ 2 Department of Animal Breeding, Animal Nutrition and Biochemistry, \\ Faculty of Veterinary Hygiene and Ecology, University of Veterinary Sciences Brno, \\ 61242 Brno, Czech Republic; sedlakovak@vfu.cz \\ * Correspondence: krizoval@vfu.cz
}

check for updates

Citation: Hadrová, S.; Sedláková, K.; Kř́ízová, L.; Malyugina, S. Alternative and Unconventional Feeds in Dairy Diets and Their Effect on Fatty Acid Profile and Health Properties of Milk Fat. Animals 2021, 11, 1817. https:// doi.org/10.3390/ani11061817

Academic Editor: Sven Dänicke

Received: 1 June 2021

Accepted: 15 June 2021

Published: 18 June 2021

Publisher's Note: MDPI stays neutral with regard to jurisdictional claims in published maps and institutional affiliations.

Copyright: (c) 2021 by the authors. Licensee MDPI, Basel, Switzerland. This article is an open access article distributed under the terms and conditions of the Creative Commons Attribution (CC BY) license (https:// creativecommons.org/licenses/by/ $4.0 /)$.
Simple Summary: Milk fat is an important compound in human nutrition. From a nutritional point of view, the production of milk with a higher content of polyunsaturated fatty acids, especially of those from the $\mathrm{n} 3$ group, is desirable because consumption of a diet with a lower $\mathrm{n} 6 / \mathrm{n} 3$ ratio is considered to be beneficial for humans. The most effective way to achieve this goal is via dietary manipulations in ruminants. In addition to the feedstuffs commonly used in dairy animal nutrition, there are some alternative or unconventional feedstuffs that are often used for other purposes, e.g., for the reduction of methane production in the rumen. However, such feedstuffs can also alter the fatty acid profile of milk, and thus they can have an impact on the health properties of milk fat.

Abstract: Milk fat is an important nutritional compound in the human diet. From the health point of view, some fatty acids (FAs), particularly long-chain PUFAs such as EPA and DHA, have been at the forefront of interest due to their antibacterial, antiviral, anti-inflammatory, and antitumor properties, which play a positive role in the prevention of cardiovascular diseases (CVD), as well as linoleic and $\gamma$-linolenic acids, which play an important role in CVD treatment as essential components of phospholipids in the mitochondria of cell membranes. Thus, the modification of the FA profile-especially an increase in the concentration of polyunsaturated FAs and n-3 FAs in bovine milk fat-is desirable. The most effective way to achieve this goal is via dietary manipulations. The effects of various strategies in dairy nutrition have been thoroughly investigated; however, there are some alternative or unconventional feedstuffs that are often used for purposes other than basic feeding or modifying the fatty acid profiles of milk, such as tanniferous plants, herbs and spices, and algae. The use of these foods in dairy diets and their effects on milk fatty acid profile are reviewed in this article. The contents of selected individual FAs (atherogenic, rumenic, linoleic, $\alpha$-linolenic, eicosapentaenoic, and docosahexaenoic acids) and their combinations; the contents of n3 and n6 FAs; $\mathrm{n} 6 / \mathrm{n} 3$ ratios; and atherogenic, health-promoting and S/P indices were used as criteria for assessing the effect of these feeds on the health properties of milk fat.

Keywords: dairy cows; health; milk fat quality; indices; algae; okara; camelina; herbs and spices; tannins

\section{Introduction}

An increased demand for milk and dairy products (especially milk and butter) has become a worldwide trend in recent years [1,2]. Fatty acids (FAs) in milk fat are considered to be important nutritional compounds in the human diet [3]. From a nutritional point of view, the production of milk with a higher proportion of polyunsaturated fatty acids (PUFAs), especially those from the $\mathrm{n}$ group, is desirable because diets with a higher content of $\mathrm{n} 3$ and a lower content of $\mathrm{n} 6$ FAs-that is, with a lower $\mathrm{n} 6 / \mathrm{n} 3$ ratio-are considered to be healthier for humans $[4,5]$. Considering the importance of PUFAs in human health and nutrition [6], the modification of the FA profile of milk fat has been a target of many studies. 
There are many factors influencing the FA profile of milk, with nutrition being the crucial one [3]. Major dietary factors, such as the type and amounts of forages or concentrates in the diet, the forage/concentrate ratio, and the supplementation of diets with fats or oil supplements, have been widely studied (reviewed recently in [3]). However, there are also some alternative or unconventional feedstuffs that are often used for different purposes (e.g., for the reduction of methane emissions or for buffering rumen $\mathrm{pH}$ ) that can affect the FA profile of milk fat. Thus, this review evaluates some of those feedstuffs from the point of view of the modern demands in relation to the health characteristics of milk fat.

\section{Milk Fatty Acids and Indices Used for the Evaluation of Milk Fat Quality}

The composition of a ruminant's diet is the main factor that can cause changes in milk FAs [3]; thus, targeted modification of the diets of ruminants can be used for the production of milk with a desirable fatty acid profile $[3,7]$ that is in accordance with the recommendations for human nutrition [7,8]. Generally, from the health point of view, it is desirable to increase the concentration of n 3 FAs in milk and dairy products and to reduce the content of certain saturated fatty acids (SFAs) - C12:0 (lauric acid), C14:0 (myristic acid), and C16:0 (palmitic acid) — as they are related to an increased risk of atherosclerosis [9].

The main n3 PUFAs are $\alpha$-linolenic acid (C18:3n3; ALA), eicosapentaenoic acid (EPA, C20:5n3), docosahexaenoic acid (DHA, C22:6n3), and the less-recognized docosapentaenoic acid (DPA, C22:5n3) [10,11]. However, it should be noted that DPA also exists in the form of $\mathrm{n} 6$ isomer and in this form it is produced by, e.g., marine microalgae from Schizochytrium spp. [12]. An essential ALA is a precursor for the production of $n 3$ long-chain (LC) PUFAs in human nutrition $[10,13]$. ALA is present in some seeds (e.g., flax) and green leafy vegetables [14]. The richest source of dietary EPA and DHA are fish (especially fatty fish) and marine algae [11,15]. EPA and DHA can be synthesized from the precursor by elongase and desaturase enzymes; however, in humans, they are not synthesized efficiently because the conversion rate is very low $[15,16]$. Some studies suggest that the conversion rate from ALA to EPA is approximately $5-8 \%$, and that $<0.5-4 \%$ of ALA is converted to DHA [17-19]. Therefore, they are essential for human nutrition and must be obtained via the diet [18]. Both these bioactive FAs are known to provide various health benefits. DHA has an important function in brain and nervous system development, in the process of vision, and in preventing inflammation $[15,19,20]$. DHA is important in the development of premature babies and small children [19], but the DHA intake is very important for adults as well. Breast milk is one of the natural sources of DHA [10]. EPA and DHA have a wide range of physiological roles linked to health benefits; thus, diets rich in fish and fish oils are related to a reduced risk of cardiovascular diseases and provide further health benefits, such as anti-carcinogenic and anti-inflammatory activity [11,21-23]. Even supplementation with both of these FAs seems to have a possible beneficial effect in the treatment of COVID-19 to prevent the occurrence of a "cytokine storm" [24]. As mentioned above, $\mathrm{n} 3$ long-chain PUFAs play a role in anti-inflammatory processes. From interleukins (a group of cytokines), interleukin- 6 and interleukin-1 $\beta$ are suspected to play a central role in cytokine storms. In addition, these cytokines can be affected by dietary EPA and DHA intake [24]. According to [10], dietary recommendations for EPA and DHA are between 250 and $500 \mathrm{mg} /$ day for adults. According to one review [25], the recommended intake of n3 LC PUFAs across health organizations is about $500 \mathrm{mg} /$ day for primary prevention of cardiovascular disease.

The n6 FAs are represented by linoleic acid (LA), which is found in the seeds of most plants [14] or in vegetable oils (reviewed by [5]). LA is also an essential FA because it cannot be synthesized by humans; respectively, humans can convert only small portions of FAs (such as LA to AA) to more than 20-carbon PUFAs [14,26]; the conversion of ingested ALA to EPA and further to DHA is not a reliable source of n-3 PUFAs [25] as the conversion efficiency is generally low [26]. Gamma-linolenic acid (GLA; C18:3n6) is a representative of the n6 FAs, and in the n- 6 pathway it is biosynthesized from LA. GLA can be found in human milk and in some vegetable oils such as borage (about 21\% GLA), blackcurrant 
(about 17\% GLA), and evening primrose oils (about 9\% GLA) [24]. Arachidonic acid (C20:4n6), on the other hand, can be obtained primarily from foods of animal origin, such as meat, poultry, and eggs [27].

Particular health promoting effects have also been observed in rumenic acid (C18:2c9t11; RA, n7)—one of the notably beneficial conjugated linoleic acid (CLA) isomers produced during ruminal biohydrogenation [28]. CLA occurs naturally in foods derived from ruminants, and RA is the predominant CLA isomer in dairy products. CLA may provide various potential health benefits, such as antiatherogenic, anticarcinogenic, and antidiabetic effects, and moreover, it can also reduce body fat (e.g., [29]).

Milk is an important energy source, containing numerous essential nutrients, such as protein, lipids, lactose, vitamins, and minerals [30]. Milk also contains various physiologically active compounds, such as nutritionally desirable FAs [31]. From the nutritional point of view, the $\mathrm{n} 6 / \mathrm{n} 3$ ratio is generally used to assess milk fat quality [8]. Diets with a lower $\mathrm{n} 6 / \mathrm{n} 3$ ratio are considered healthier for humans [5] due to the reduced risk of many chronic diseases. According to [4], a very high ratio, i.e., excessive amounts of n6 PUFAs, promotes the pathogenesis of many chronic diseases. On the other hand, the increased intake of $n 3$ FAs can lead to a lower risk of cardiovascular diseases [32]. The optimum dietary $n 6 / \mathrm{n} 3$ ratio should be around 1-4:1 [14,33]; however, the ratio in a typical Western diet varies between 10:1 and 20:1 [14].

Aside from the $\mathrm{n} 6 / \mathrm{n} 3$ ratio, milk fat quality can be evaluated through some proposed indices, such as the atherogenic index, thrombogenic index, health-promoting index, or hypo-/hypercholesterolaemic ratio [34-36]. These indices take into consideration the fact that SFAs with chain lengths of 12 to 16 carbons are considered to be atherogenic [37].

According to [34], the atherogenic index (AI) and thrombogenic index (TI) are markers that indicate a potential risk of cardiovascular diseases. They are calculated as follows:

$$
\mathrm{TI}=(\mathrm{C} 14: 0+\mathrm{C} 16: 0+\mathrm{C} 18: 0) /\left[\left(0.5 \times \sum \text { MUFA }+0.5 \times \sum \text { PUFA (n6) }+3 \times \sum \text { PUFA (n3) }\right)+(\mathrm{n} 3) /(\mathrm{n} 6)\right] .
$$

The health-promoting index (HPI) is the inverse of the atherogenic index [9,35]:

$$
\mathrm{HPI}=\left(\sum \mathrm{MUFA}+\sum \mathrm{PUFA}\right) /(\mathrm{C} 12: 0+4 \times \mathrm{C} 14: 0+\mathrm{C} 16: 0)
$$

Hypocholesterolaemic/hypercholesterolaemic ratio $(\mathrm{h} / \mathrm{H})$ is calculated according to the following formula [36]:

$\mathrm{h} / \mathrm{H}=(\mathrm{C} 18: 1 \mathrm{n} 9+\mathrm{C} 18: 2 \mathrm{n} 6+\mathrm{C} 20: 4 \mathrm{n} 6+\mathrm{C} 18: 3 \mathrm{n} 3+\mathrm{C} 20: 5 \mathrm{n} 3+\mathrm{C} 22: 5 \mathrm{n} 3+\mathrm{C} 22: 6 \mathrm{n} 3) /(\mathrm{C} 14: 0+\mathrm{C} 16: 0)$.

From the health point of view, milk fat with low $\mathrm{AI}$ and TI values and, on the contrary, with a high HPI index and $\mathrm{h} / \mathrm{H}$ ratio is desirable, because it is a sign of a lower risk of cardiovascular diseases [38]. In addition to these indices, ratios of PUFA/SFA and S/P ratio (see the formula below) are used to evaluate the nutritional value of milk fat as well [38].

$$
\mathrm{S} / \mathrm{P}=(\mathrm{C} 14: 0+\mathrm{C} 16: 0+\mathrm{C} 18: 0) /\left(\sum \mathrm{MUFA}+\sum \mathrm{PUFA}\right)
$$

On the other hand, a higher proportion of PUFAs in milk fat is connected with the impaired technological properties of milk fat. Increased PUFAs in milk fat can have both positive and negative effects on these properties. Although a positive effect is represented by an improved spreadability of milk fat, a negative effect is represented by an increased susceptibility to oxidation. Thus, to evaluate the effect of a modified proportion of milk FAs on the technological properties of milk fat, the spreadability index (SI) can provide a deeper insight into the quality of milk fat and can be calculated according to the following formula [39]:

$$
\mathrm{SI}=\mathrm{C} 18: 1 \mathrm{c} 9 / \mathrm{C} 16: 0
$$


Furthermore, an important parameter of milk fat synthesis is the ability of the mammary gland to desaturate FAs originating from the blood (derived from the diet or microbial activity in the rumen) or from de novo synthesis with the help of the stearoyl-CoA desaturase (SCD) enzyme, which catalyses the introduction of a cis-double bond between carbon atoms 9 and 10 of FAs with a chain length of 10 to 18 carbons [3]. To characterize this process, desaturation indices (DI) are calculated from the amount of specific SFAs and corresponding MUFAs as a percentage of the product from the sum of the product and the substrate [40]. The following product and substrate pairs can be taken into calculations:

$$
\begin{gathered}
\text { DI }(\mathrm{C} 14)=(\mathrm{C} 14: 1 \mathrm{c} 9) * 100 /(\mathrm{C} 14: 0+\mathrm{C} 14: 1 \mathrm{c} 9) \\
\text { DI }(\mathrm{C} 16)=(\mathrm{C} 16: 1 \mathrm{c} 9) * 100 /(\mathrm{C} 16: 0+\mathrm{C} 16: 1 \mathrm{c} 9) \\
\text { DI }(\mathrm{C} 18)=(\mathrm{C} 18: 1 \mathrm{c} 9) * 100 /(\mathrm{C} 18: 0+\mathrm{C} 18: 1 \mathrm{c} 9) \\
\text { DI }(\mathrm{RA})=(\mathrm{C} 18: 2 \mathrm{c} 9 \mathrm{t} 11) * 100 /(\mathrm{C} 18: 1 \mathrm{t} 11+\mathrm{C} 18: 2 \mathrm{c} 9 \mathrm{t} 11)
\end{gathered}
$$

\section{Alternative and Unconventional Feeds Used in Dairy Diets}

\subsection{Macroalgae and Microalgae}

Algae belong predominantly to the group of photosynthetic organisms that can grow in a range of aquatic habitats. However, many photosynthetic species (e.g., Chlorella, Scenedesmus, Hamaetococcus, Spirulina, and Nostoc) are able to grow heterotrophically, using organic substrates as sole sources of carbon [41,42]. Marine algae generally contain a wide spectrum of valuable, biologically active compounds, such as polysaccharides, proteins, PUFAs, various pigments, antioxidants, etc. Considering this spectrum, it predestines them to diverse commercial applications. According to their size, algae are divided into macroalgae (large-sized algae) and microalgae (microscopic single cells) [41].

\subsubsection{Macroalgae}

Macroalgae (also called seaweeds) generally reside in the littoral zone [43]. According to the presence of specific pigments, macroalgae are divided into three major groups: Rhodophyta (red algae), Phaeophyta (brown algae), and Chlorophyta (green algae) [23,43]. Ascophyllum nodosum, Laminaria sp., Lithothamnion sp., Macrocystis pyrifera (giant kelp), Sargassum sp., Palmaria palmata, and Ulva sp. are the main genera and species which have the potential to be used as animal feeds [43]. Although the nutritional value of seaweeds has been reviewed recently [44], it is worth mentioning some specific polysaccharides, such as fucoidan, a sulphated polysaccharide found in the cell walls of brown macroalgae that exerts antitumor, antithrombotic, and antiviral properties [23,45]; laminarin, a polysaccharide isolated from brown seaweed [46]; and ulvan, found in green algae of Ulva sp. [47], with various biological activities. Furthermore, macroalgae are also an excellent source of minerals and trace elements, vitamins, and other bioactive compounds such as pigments [23]. Despite having a low content of lipids (1-5\%), macroalgae are rich in PUFAs (reviewed in $[23,44]$ ), namely, EPAs and AAs, found mainly in brown and red seaweeds $[44,48]$. However, it should be noted that the chemical and nutritional composition of seaweeds is highly variable, depending on many factors [23,44,48].

Among their diverse applications, seaweeds are also considered to be a suitable feed additive for livestock animals. However, scientific data concerning the effect of macroalgae supplemented into ruminant diets on milk yield and composition are limited, [49,50] reported an increase in milk fat yields in dairy cows supplemented with the calcareous red alga Lithothamnion calcareum, which was used as a buffer. Caroprese et al. [51] demonstrated the positive effect of brown alga Ascophyllum nodosum on the performance of lactating ewes. They reported increased milk yield and total n3 FAs; the highest n3/n6 ratio was found in milk from ewes supplemented with flaxseed in combination with Ascophyllum nodosum compared to controls; furthermore, flaxseed and flaxseed + brown algae decreased AI and TI. Quigley et al. [52] reported an increase in $\delta$-tocopherol in the milk of cows supplemented 
with $A$. nodosum. On the other hand, the addition of the brown alga Undaria pinnatifida (in a mixture of brown seaweed, pinecone oil, and garlic extracts, respectively) or the red seaweed Gracilaria birdiae to lactating diets did not affect cows' or goats' milk performance, respectively $[53,54]$. Recently, a positive effect of some algal species on the mitigation of methane emissions in ruminants has been demonstrated. Among macroalgae, the red seaweed Asparagopsis armata seems to be particularly efficient in the reduction of methane production $[55,56]$.

\subsubsection{Microalgae}

Microalgae are a morphologically diverse group of aquatic unicellular or multicellular microorganisms with a range of 0-200 $\mu \mathrm{m}$. [57]. Generally, microalgae are considered photoautotrophic organisms, whereas a number of species (e.g., Schizochytrium) are heterotrophic. Microalgae show high metabolic flexibility and most of them are able to grow under both autotrophic and heterotrophic conditions (mixotrophic algae) [58].

Microalgae produce a wide range of bioactive compounds, such as PUFAs, pigments, and antioxidants, so they can be used as supplements not only in human diets but also in animal diets $[59,60]$. Indeed, about $30 \%$ of the current world algal production is sold for animal feeding purposes [61] and Spirulina (Arthrospira) and Chlorella sp. belong to major microalgae, with possible applications in human and animal nutrition [59]. However, the higher cost of Chlorella biomass production limits its wider usage as a protein supplement in animal diets [62]. On the other hand, the content of desirable substances (e.g., PUFAs) in microalgae can be modified by external factors such as temperature or light intensity during cultivation $[59,63]$. Furthermore, the nutrient profile can be altered by engineering a number of enzymes (desturases and elongases) and transcription factors [64] or by filtering light [65]. Furthermore, the selection of microalgal species plays a role because some strains from the Nannochloropsis, Phaeodactylum, Schizochytrium, Arthrospira, and Thraustochytrium genera can accumulate high contents of EPA, DHA, and/or $\gamma$-linolenic acid [59,63,66-68].

Chlorella is among the most cultivated eukaryotic microalgae and is used as a food supplement and feed additive. Chlorella contains 50-60\% crude protein (\% dry matter) $[69,70]$ and well-balanced essential amino acids [70]; thus, Chlorella represents an excellent novel protein source. Furthermore, an important substance in Chlorella seems to be $\beta$-1,3-glucan [71]. In addition, Chlorella species, e.g., Chlorella kessleri, are also notably high in C18:3 (n3) [8]. Spirulina, e.g., Arthrospira maxima, or blue-green algae (cyanobacteria), is also known to have a high protein content-60-71\% depending on the strain; dried spirulina biomass contains all the essential amino acids, with excellent bioavailability $[60,69,72]$. Moreover, spirulina is a rich source of carotenoids and FAs and contains about $1.7 \%$ of total PUFAs, of which linoleic and $\gamma$-linolenic acids account for $45 \%[23,73,74]$.

Another microalga that is commercially used as a food supplement or can be used as a supplementary feed additive is the green alga Haematococcus pluvialis, which accumulates the carotenoid pigment astaxanthin, and which has been recognized as the richest natural source of this pigment [59]. Astaxanthin is known especially for its strong antioxidant activity that provides various health benefits [75]. Dunaliella salina is a halotolerant microalga with potential for use in food and feed applications due to its ability to accumulate large amounts of $\beta$-carotene $[59,66]$; moreover, it can also produce high-quality protein [76]. A green microalga, Scenedesmus almeriensis, is a rich source of the carotenoid lutein [66].

Microalgae can positively affect the quality of bovine milk because EPA and DHA can be transferred from the diet into milk [58], so it can be an effective way to reduce the amount of potentially atherogenic FAs in milk, such as lauric, myristic, and palmitic FAs [77].

For the manipulation of the FA composition of milk, microalgae can be supplemented into the cow diet in different forms, as microalgal biomass (defatted or full-fat) or oil [69]. There is a relatively large amount of PUFAs in the feed rations of ruminants; however, the transfer of EPA and DHA from the diet into milk can lead to limited results due to the extensive biohydrogenation of these FAs in the rumen (if they are unprotected), which is 
the reason the transfer efficiency is low $[13,58,78-80]$. Thus, the efficiency of the transfer of unsaturated FAs from feed to milk depends on the effectiveness of their protection in the rumen $[81,82]$. When some protected sources of n-3 LC PUFAs are involved in the diets of dairy cows, such as protected fish oil, the transfer efficiency of both EPA and DHA into the milk can be increased, although even when feeding animals with food from protected sources, the response to increased EPA and DHA can be still low $[13,83]$. Biologically active compounds in microalgae are protected thanks to the special composition of the cell wall and cell membranes [82]. Therefore, the addition of marine-derived supplements seems to be an efficient method of producing n3 PUFA-enriched milk. The results of some studies (e.g., $[8,84,85])$ have shown that the inclusion of microalgae in the diet of dairy cows can affected the FA profile of their milk, mainly in the content of rumenic acid and $\mathrm{n} 3 \mathrm{FAs}$, the $\mathrm{n} 6 / \mathrm{n} 3$ ratio, and the transfer efficiency of DHA from the diet into milk fat. However, in [86] it was observed that changes in milk fat composition depend on the dose of algal supplementations, e.g., graduated doses of microalgae that are rich in DHA in the diets of dairy cows resulted in reduced SFA content, whereas the proportion of PUFAs, C18:2cis9t11, and other FAs were significantly increased [84]. In [8], the n3 FA levels were higher in microalgae-supplemented cows compared to controls, and [79] reported increased levels of DHA in the milk of cows fed a silage-based diet with microalgae supplementation. Similarly, the positive effect of microalgae supplementation on DHA content, DPA, and EPA in the milk of small ruminants has been reported [8,87-89].

\subsection{By-Products of the Food Industry}

\subsubsection{Okara Meal}

In Japan and other parts of eastern and Southeast Asia, soybeans are commonly used to make various foods, such as tofu, soymilk, tempeh, soybean oil, soy flour, and soy sauce. During the processing of soy milk and tofu, the soybeans are ground and water is used to obtain water-extractable fractions. The main residue from this processing is okara [90,91]. About $1.1 \mathrm{~kg}$ of fresh soybean curd residue is produced from each kilogram of soybeans processed into soy milk or tofu [91]. The stability of fresh okara is relatively low and should therefore be used quickly. Fresh okara has a high moisture content (from $70 \%$ to $80 \%$ ), which makes it difficult to handle, and it is too expensive to dry it by means of conventional methods [92]. Suitable ways of incorporating okara into feed are currently being sought that would add economic value to the product and eliminate a possible source of contamination $[93,94]$. Although okara is a highly nutritionally valuable product, it is often landfilled or disposed of via incineration [90], which is accompanied by the release of carbon dioxide [91]. Due to its susceptibility to rot and excessive residue formation, the disposal of soybean curd residues poses a potential environmental problem [95-97]. However, soy curd residue is widely recognized for its high nutritional value and excellent functional properties as a relatively inexpensive source of protein [91,98]. There is only a small amount of okara, which is sometimes used for feeding purposes [90]. For example, in the United States, part of the okara, which comes from the production of organically certified soy milk and tofu, is used for feeding purposes in organic herds [99]. Due to differences in sources and processing methods, the nutritional value of okara is very variable. Crude protein concentrations range from $16 \%$ to $33 \%$, ether extract from $0.8 \%$ to $22 \%$, carbohydrates from $2.6 \%$ to $54 \%$ and fiber from $4.5 \%$ to $58 \%$ [91]. In addition, okara is rich in long-chain FAs and the isoflavones daidzein and genistein $[100,101]$. It was reported that $50 \%$ of the total FAs present in freeze-dried and ground okara consisted of $\mathrm{C} 18: 2 \mathrm{c} 9 \mathrm{c} 12$, which is slightly less than that reported for soybean meal (52\% of the total FAs; [101,102]). Several studies have been conducted to investigate the effect of moist okara in diets on ruminants, and no adverse effects on dry matter intake and production performance have been reported [103-106]. Improved dry matter intake and apparent total tract digestibility of dry matter, organic matter, and NDF have been observed in mature lambs fed with TMR containing wet okara silage [107]. However, all the above-mentioned studies used wet or ensiled okara. Research focused on the use of dried okara (i.e., okara meal) as a protein 
source in lactating dairy cows is lacking. Recent results have proved that okara meal is a suitable replacement for soybean meal in dairy diets, without negative effects on lactation performance and dry matter intake [99].

\subsubsection{Camelina sativa Seeds or Expellers}

Camelina (Camelina sativa L.) is an oil plant belonging to the Brassicaceae family and has often been referred to as "false flax" [108]. This annual or hibernating herb originates from the Mediterranean to Central Asia and thus represents an alternative source in the context of adaptive and resilient ruminant farming systems [109,110]. Camelina is a low-input oil seed crop with very high nutrient efficiency that can grow with limited nitrogen fertilization [111,112]. In addition, camelina has a relatively short growing season of about 4 months and can therefore be integrated into double-growing systems during cold growing periods [113]. Many studies of camelina have highlighted its potential as a promising oilseed crop for sustainable farming systems [111]. A by-product of the oil industry, camelina-rich press-cake is a valuable feed for livestock. This oilseed meal still contains $10 \%$ oil, $13 \%$ fiber, $5 \%$ minerals, and $45 \%$ protein [110]. Camelina seed contains $40-44 \%$ crude protein and $39-47 \%$ fat [114] and is interesting as a source of protein and energy in the ratio of high-yielding dairy cows [112]. It has a similar FA profile to flaxseed and is rich in linolenic acid. Camelina oil contains $20 \%$ to $40 \%$ C18:3 (mainly $\alpha$-linolenic acid), $10 \%$ to $20 \%$ C18:2 (mainly linoleic acid), $12 \%$ to $25 \%$ C18:1, $13 \%$ to $21 \%$ C20:1 and $2 \%$ to 5\% C22:1 [110,114-116]. Camelina seeds and their by-products contain antinutritional factors that limit their use in animal feeds. Camelina seeds contain glucosinolates, which induce a lower activity of the thyroid gland and cause disturbances in metabolism. The growing environment of camelina has been reported to influence its glucosinolate content. The main glucosinolates identified in CE and WCS were glucoarabin, glucocamelein, and gluconesliapaniculatin, with slightly lower concentrations in CE [111,117]. Camelina seeds contain sinapine, which is important in plants for the biosynthesis of lignin and flavonoids. However, sinapine has several properties that are undesirable as a constituent in animal feeds [118]. Camelina oil also contains small amounts of C22:1c13 (erucic acid; $2-6 \%$ of total FA) [115]. Potential health concerns are associated with the dietary consumption of this FA because experimental studies have demonstrated an association between dietary cis-13 22:1 and heart disease [117]. It is therefore of interest to quantify the magnitude of transfer of this FA from dietary CE or WCS to milk fat in lactating ruminants [117]. Camelina seeds are also relatively abundant in essential amino acids [114], highlighting the potential of camelina as a high-quality feed for ruminants. Several studies have shown that the usage of camelina seeds, cakes, or oil can alter the milk fat composition in cows fed with diets based on maize silage [99], red clover silage [119], or grass silage [116,120]. Similar effects were also observed in goats and sheep [121-123].

\subsection{Tanniferous Plants}

Some dietary phenolic compounds can be beneficial for human health. Recognized benefits include the inhibition of oxidative stress and cell destruction associated with degenerative diseases and modern lifestyle [124], protection against oxidative damage [125], and the prevention of chronic diseases [126].

Important amounts of phenolic compounds, especially flavonoids, are contained in grape seeds [127]. Grape oil flour has been studied for its reducing effect on methane emissions. It has been found that the addition of grape seed meal favorably modulates rumen fermentation by reducing methane production, without adversely affecting fiber degradation. It can help to stabilize rumen $\mathrm{pH}$ in a grain-rich diet by forming complexes with some rapidly degradable carbohydrates [128]. The whole grain seeds contained in the lamb diet cause higher weight gain. Increasing the levels of grape seed meal were shown to reduce saturated fatty acids, increase unsaturated fatty acids, and improve the eating properties of meat, with good atherogenicity and thrombogenicity indices [129]. A number of experiments with ewes have examined the effects of the dietary classification of grape 
seeds on milk production and milk quality [130]. Experiments have suggested that grape seeds may be useful for increasing the concentration of polyunsaturated fatty acids, with potential health benefits for consumers [131]. The addition of grape seeds reduced the extent of oxidation of total unsaturated fatty acids in milk [132].

Phenols, especially tannins, can inhibit or counteract the rumen biohydrogenation of polyunsaturated FAs (PUFAs), such as ALA and LA $[133,134]$. Depending on the effects on rumen biohydrogenation, tannins are commonly divided into two main classes. These are insoluble condensed tannins that have a very high molecular weight. Their formation occurs through the polymerization of flavon-3-ol and is characterized by an inhibitory effect on rumen biohydrogenation [135]. On the other hand, soluble hydrolyzable tannins are non-flavonoid compounds that also appear to have a modulatory effect on rumen biohydrogenation [135]. Tannins inhibit microbes that are involved in rumen biohydrogenation through mechanisms that are not yet clear. The fact remains that the effects of tannins are modulated by the potential adaptation of the rumen microflora to these phytochemicals, as well as by chemical composition, macronutrient interactions, as well as the dose $[135,136]$. Based on the results of in vitro and in vivo studies, it was observed that tannins exert differing effects on the rumen bacteria involved in lipolysis, the first step of rumen biohydrogenation, and specifically the conversion of ALA and LA to vaccenic acid (VA) and VA to C18:0 [135]. Various theories apply to this issue. One is that tannins can exhibit toxic effects by altering the permeability of bacterial membranes [137]. Another theory is that tannins reduce rumen biohydrogenation by inhibiting rumen microbial activity, rather than by inhibiting their enzymatic activity. This inhibition is not constant but affects different rumen biohydrogenation steps at different rates [138]. Selected additives may also improve the feeding efficiency of dairy cattle. The potential of tannins (hydrolyzable and condensed) to increase the utilization of proteins in the diet of ruminants is associated with their ability to bind proteins in the rumen and thus prevent their excessive microbial degradation. Tannin-protein complexes are dissociated in acidic $\mathrm{pH}$ in the abomasum or under alkaline conditions of the small intestine, releasing the protein for digestion and absorption [139]. Some tannins added to ruminant diets have also been shown to reduce methane production in the rumen without adversely affecting the efficiency of fermentation in the rumen [140-142].

\subsection{Herbs and Spices}

\subsubsection{Oregano}

Herbs or medicinal plants, including oregano (Origanum vulgare), contain essential oils (EOs), volatile plant secondary metabolites that give plants a characteristic odor and taste [143]. They protect plants from damage by microorganisms, herbivores, and UV$\mathrm{B}$ radiation [144]. Essential oils have strong and non-specific antimicrobial properties; however, microbes show different levels of sensitivity to EOs [143,145]. Oregano is a perennial herb that grows in Eurasia and North Africa. The EO content of Greek oregano (Origanum vulgare ssp. hirtum) is high, approximately $4 \%$ of the dry matter $[146,147]$. Another subspecies of oregano, wild marjoram (Origanum vulgare ssp. vulgare), has naturally lower levels of EOs, with a concentration of only $0.2 \%$ dry matter and up to $1 \%$ dry matter $[146,147]$. The effects of low-EO oregano (O. vulgare ssp. vulgare) and high-EO oregano plant material (O. vulgare ssp. hirtum) on methane production, rumen fermentation, nutrient digestibility, and milk fatty acid composition were studied recently [148]. Dry matter intake was not affected by feeding with low- or high-EO oregano, suggesting that doses of oregano administered to cows did not affect digestibility. DMI was not affected by the administration of oregano [149] or oregano EO [150]. As in recent studies [148-152], it does not affect milk yield. The effect on milk composition has only been studied in some studies that report either increased or decreased fat and protein contents $[149,150,152]$. Oregano with or without a high level of EO does not appear to affect feed conversion efficiency, despite the fact that the literature refers to carvacrol and thymol as being similar to ionophore antibiotics [153]. In contrast, improved feeding efficiency with 3.5\% FCM per 
kilogram of DMI [149] and a kilogram of milk per kilogram of DMI has been previously reported [151].

\subsubsection{Hop Plants}

Hops (Humulus lupulus L.), which are added to beer as preservatives, are a potential additive to reduce rumen $\mathrm{CH}_{4}$ emissions and protein degradation. The antimicrobial components of hops-including humulone, lupulon (commonly called $\alpha$ - and $\beta$-acid), and their isomers-inhibit lactic acid bacteria, which spoil beer [139]. The types of hyper- $\mathrm{NH}_{3}$ producing bacteria present in the rumen are sensitive to the antimicrobial components of hops. Hops used in in vitro experiments reduced the degradability of dry matter and crude protein in the rumen without affecting the digestibility of DM and CP [154]. The inclusion of hops at between 400 and $800 \mathrm{mg} / \mathrm{L}$ of culture fluid in in vitro rumen incubations reduced $\mathrm{CH}_{4}$ production and the acetate/propionate ratio $[155,156]$. Hops thus appear to be another promising natural feed additive in reducing the production of $\mathrm{CH}_{4}$ in the rumen [139]. When used in combination, hop pellets and oak extracts can complement each other to reduce rumen $\mathrm{CH}_{4}$ production and $\mathrm{NH}_{3}$ efflux in ruminants [156]. There is a lack of published information on the effect of hops on milk production and milk composition in cows. Hop pellets did not affect milk production or milk composition. In contrast, dietary supplementation with a combination of hop pellets and tannin extracts increased milk production and protein yield. Similarly, no published scientific work is available on the effect of hops on rumen biohydrogenation. Hop $\alpha$ - and $\beta$-acids inhibit most Gram-positive bacteria in a similar manner to monensin [155]. The antimicrobial activity of hops is similar to that of monensin. Therefore, the inhibition of FA biohydrogenation, leading to higher levels of UFA in milk, could be expected. Hops alone at the tested dose had no significant effect on the fatty acid profile of milk. This dose was either too low or the rumen microbes were adapted to hops [139].

\subsection{Other Plants}

\subsubsection{Cactus Cladodes}

Cacti of the genus Opuntia (commonly referred to as prickly pear cactus) are an important source of feed for ruminants in the semi-arid regions of Brazil and other arid regions around the world. The ability of cacti to thrive in severe drought conditions is remarkable [157]. Cactus has a high moisture content in its cladodes and can therefore meet a significant part of the water requirements for livestock [158]. In contrast to traditional feeds, cladodes from Opuntia spp. contain approximately $250 \mathrm{~g}$ of neutral detergent fiber (NDF) and 500-600 g of non-fiber carbohydrates (NFC) per kg of dry matter (DM) [159]. Cactus cladodes thus contain high levels of digestible energy, which leads to a reduction in the proportion of concentrates, such as cereal grains, in ruminant diets. Several studies have addressed the effects of cactus feeding on rumen fermentation and production performance [159]; however, information on the effect of cactus cladodes on the FA composition of bovine milk is scarce. In cows fed with cactus cladodes, a low proportion of 18:0 in milk fat $(<5 \mathrm{~g} / 100 \mathrm{~g}$ total FAs) was observed, regardless of the composition of the basal diet [160]. This observation could be associated with a low lipid content in cladodes $(10-15 \mathrm{~g} / \mathrm{kg} \mathrm{DM})$, which in turn would lead to low rumen production of 18:0 due to a reduced dietary intake of PUFAs for rumen biohydrogenation [160]. However, the 18:0 content of the milk fat of cows fed with a sugar cane diet was only slightly lower than the levels normally reported for a conventional dairy diet $[161,162]$. This fact suggests that other mechanisms may account for the reduced 18:0 content observed in the milk fat of cows consuming cacti. A possible mechanism could be faster permeability of the rumen digestive tract, which is expected to shorten the exposure time of feed particles to rumen bacteria, leading to less complete $\mathrm{BH}$ of dietary PUFAs [163]. This hypothesis is supported by the presence of large feed particles in the feces of cows fed with a diet containing high proportions (350-500 g/ $\mathrm{kg} \mathrm{DM}$ ) of cactus cladodes [148]. Alternatively, the presence of numerous phenolic compounds in the cladodes of Opuntia spp. [164,165], including Opuntia stricta [166,167], can alter the 
microbial population of the rumen by inhibiting the bacterial species responsible for the last step in rumen biohydrogenation [135]. This finding, regardless of the mechanisms underlying the 18:0 reduction in the milk fat of cows fed with cactus cladodes, suggests that combining cladodes with PUFA-rich vegetable oils may increase the rumen accumulation and outflow of the 18:1 trans-11 for the mammary synthesis of cis-9, trans-11-conjugated linoleic acid (CLA), thereby improving the nutritional quality of milk fat [81].

\subsubsection{Blue Lupine}

Several species of lupine (e.g., Lupinus albus, Lupinus luteus, and Lupinus angustifolius) have been commonly used in animal diets. To date, the dietary use of lupins in ruminants has been studied mainly for its high protein content as a potential substitution for soybean meal [168]. Indeed, lupines contain comparable amounts of protein with a similar amino acid profile, and the digestibility of lupine protein is comparable to the digestibility of soy protein [169]. On the other hand, lupines have a higher fiber content, which is nutritionally favorable compared to soybeans [170,171]. Furthermore, studies on lupine as a source of valuable nutrients for ruminants are of growing interest due to their positive effect on the animal production and biological value of animal products, e.g., on the FA profile of milk fat, as documented for L. albus [171-173]. In recent years, blue lupine (L. angustifolius) has been widely introduced as a potential source of livestock feed. Its seeds are high in protein, at $330 \mathrm{~g} / \mathrm{kg}$ dry matter, and in non-starch polysaccharides, at $400 \mathrm{~g} / \mathrm{kg}$ dry matter, composed mainly of a non-cellulosic polymer and pectin polysaccharides $[168,171]$.

\subsubsection{Olive Leaves and by-Products}

The olive tree (Olea europaea L.), a member of the Oleaceae, is a slow-growing evergreen tree that is essentially native to the Mediterranean climate [174]. The term olive leaves refers to a mix of leaves and branches obtained from olive tree pruning and olive harvesting and cleaning [175]. Such a mix appears to be a copious by-product, representing (approximately) $10 \%$ of the total weight of harvested olives [176], and accounting for almost $5 \%$ of overall yield from olive oil by-products [177]. These residues could be useful for the feeding of small ruminants when there is a lack of availability of forages [178]. Actually, olive leaf by-products may play an important role in the integrated use of the available resources and reducing environmental impacts [178]. The increasing amount of these residues represents a major problem due to their adverse effects on environmental sustainability [179]. This underutilized biomass could be regarded as a valuable resource in the food sector, as it is useful in the production of additives, credited with prominent antioxidant, antiinflammatory, and antimicrobial activities $[179,180]$. The high biological value of this by-product is due to the presence of well-known and well-characterized phenolic bioactive compounds, such as caffeic acid, tyrosol, hydroxytyrosol, flavones (apigenin, kaempferol, and luteolin), and oleuropeosides (oleuropein and verbascoside) [181]. Olive leaves can be used as a resource in the zootechnical field as a dietary supplement for farm animals. Recent studies show that olive leaves can induce positive effects when integrated into animal diets [174]. Several factors (e.g., sampling period, cultivar, age of the olive tree, climatic changes, and the process of obtention) affect olive leaf composition. The average composition of an olive leaf is $49.8 \%$ moisture, $7.6 \%$ proteins, $1.1 \%$ lipids, $4.5 \%$ minerals, and $37.1 \%$ carbohydrates. Olive leaves are characterized by a high level of fiber and lignin [182].

\section{Effect of Alternative and Unconventional Feeds on Selected Fatty Acids and Health Properties of Milk Fat}

The effects of alternative and unconventional feedstuffs used in dairy diets on selected FAs, their sums, ratios, and indices describing the health and technological properties of milk fat, are described in Tables 1-4. The majority of these feeds were included in TMR diets based on preserved feeds, mainly silages/baleages made from maize, grasses, legumes, sorghum, or their mixtures or hay (grass, lucerne) and concentrated feeds, represented predominantly by maize, barley/wheat, and soybean meal (see Table 1). The 
rate of inclusion of these feeds into the animals' diets differed according to the major nutrients for which they were included into the diet (sources of protein, minerals, FA, etc.), the feeds' properties (effect on palatability, presence of antinutritive substances), or their availability and form (extracts, natural feeds). Although macroalgae, such as Ascophyllum nodosum, are used mainly for their high content of macro- and microminerals, polysaccharides, polyphenols, and bioactive peptides [183], microalgae are rich in crude protein and/or long-chain PUFAs, especially EPA, DHA, and linoleic and/or $\gamma$-linolenic acid $[59,63,66-68]$. The algal components were generally given in amounts ranging from 100 to $310 \mathrm{~g} / \mathrm{d}$ on an as-fed basis (see the Table 1), except for the situation in which the microalgae were used as a protein substitution for soybean meal in daily amounts ranging from 1.12 to $1.63 \mathrm{~kg} \mathrm{DM} / \mathrm{d}$ [67]. As mentioned, microalga; supplementations are used to increase the content of n3 FAs in milk, mainly ALA, EPA, and DHA, and to improve the $\mathrm{n} 6 / \mathrm{n} 3$ ratio $[59,63,66-68]$. It seems that the highest potential for such improvement is in Schizochytrium sp. and in a combination of Chlorella + Nannochloropsis (Tables 2 and 3).

Compared to algal products, industrial by-products such as okara meal or camelina expellers, as protein sources, were incorporated into dairy diets in higher proportions, at $150 \mathrm{~g} / \mathrm{kg}$ DM or $2.4 \mathrm{~kg} / \mathrm{d}$ as-fed, respectively. In the case of the inclusion of whole camelina seeds, the rate was lower, at $42 \mathrm{~g} / \mathrm{kg} \mathrm{DM}$, due to a presence of antinutritive substances, as described above. Furthermore, these products are also rich in C18:1c9, C18:2n6, and C18:3n3 (see Table 1), so they seem to be especially efficient in increasing the total PUFA and n3 FA contents in milk fat $[117,119]$, resulting in favourable $n 6 / n 3$ ratios (Table 3 ).

Tannins are used primarily for the modification of biohydrogenation processes and protein digestion in the rumen; some of them have also been used to reduce methanogenesis. However, tannin extracts are expensive and may reduce the palatability of diets. This is why various tanniferous plants were tested as an alternative to tannin extracts [183]. Aside from their phenol contents, tanniferous plants are rich in C16:0, ranging from 19.7 to $47 \mathrm{~g} / 100 \mathrm{~g} \mathrm{FA}$, according to plant species, and in C18:1c9, C18:2n6, and C18:3n3 (see Table 1). They can also induce changes in milk FAs by altering the course of rumen biohydrogenation. These effects were mainly obvious in minor FAs (C15:0-C17:0), the longchain FAs (mainly ALA), and intermediates of ruminal biohydrogenation (VA, RA) [183]. Among the reviewed tanniferous compounds, oak tannins (heartwood) seem to be the most efficient in reducing SFAs and increasing MUFA and PUFA contents (see Table 3). Herbs and spices such as oregano or garlic contain EOs that are thought to be efficient in lowering methane emissions, which is the primary reason why they have been tested in dairy diets. Furthermore, the production of $\mathrm{CH}_{4}$ represents losses of dietary energy ranging between $2 \%$ to $12 \%$, depending on the diet [184]. Due to their strong antimicrobial properties, EO can also alter rumen fermentation by inhibiting fibrolytic bacteria or by reducing the abundance of Archaea [148], thus improving the digestibility of nutrients and increasing the amount of energy available for animal production. After supplementation with high-EO oregano, no effect on milk FA was observed [148]. On the other hand, feeding with low-EO oregano increased the content of ALA in milk fat [148]. The discrepancies in animal responses to EOs suggests that not only the dose, but also the form in which the EOs are supplied (EO as a supplement vs. as a natural plant/forage component), is important $[148,151,152]$. Therefore, the form of inclusion of herbs and spices into dairy diets should be also considered when examining their effects on the specific or secondary aspects of animal production, such as the FA profile of milk. Compared to oregano EOs, the information about the effect of hops on rumen fermentation and milk performance is scarce. Although the inhibitory effects of hops' bitter-tasting acids on most Gram-positive bacteria have been reported [155] no changes in milk FA profiles, nor in $\mathrm{CH} 4$ emissions, DM, or organic matter, were noted, suggesting that the dose tested ( $56 \mathrm{~g} / \mathrm{kg}$ DM, Table 1$)$ was too low [139]. Further studies are needed to clarify the effect of hops or their active substances on the course of fermentation, biohydrogenation, and methanogenesis in the rumen.

Among the other feedstuffs, cactus cladode silage was included in the diet in the amount of $340 \mathrm{~g} / \mathrm{kg}$ DM and, aside from its main nutrients, it was rich in C16:0 and linoleic 
acid and ALA. Feeding with cactus cladode silage seems to be beneficial in terms of a decreased content of milk SFAs and increased contents of MUFAs and PUFAs, namely, $\mathrm{VA}$ and RA. Although the $\mathrm{n} 6 / \mathrm{n} 3$ ratio was relatively high, the AI was low due to the low contents of atherogenic FAs C12:0, C14, and C16:0 (Tables 1-4).

Generally, among the reviewed feeds, some microalgae of Schizochytrium spp. [85,86], Chlorella vulgaris [77], rumen-protected algae [79,185], and blue lupine can be thought to be efficient in improving the n6 FA content in milk fat (Table 3). On the other hand, feeding with tanniferous plants, by-products, Spirulina platensis, Ascophyllum nodosum, Aurantiochytrrium limacinum [186], and Schizochytrium spp. [187] resulted in low n6 FA contents in milk fat (Table 3). In the case of n3 FAs, low contents in milk were found after using Ascophyllum nodosum, Aurantiochytrium limacinum [186], Spirulina platensis, and camelina expeller [117] for the feeding of dairy cows. On the other hand, tanniferous plants, some Schizochytrium spp. [86,187], and camelina expeller [119] feeding resulted in elevated $\mathrm{n} 3 \mathrm{FA}$ in milk. The corresponding n6/n3 ratio varied from values as low as 0.39 or 0.45 , found in whole camelina seeds and camelina expeller, respectively, to values as high as 11.2 in blue lupine or 6.78 in Schizochytrium limacinum in [77].

Generally, among the reviewed feeds, the highest content of C12:0 was found in milk fat after feeding with all tanniferous plants, fed in the form of plant components (not extract) [183], and the lowest content was found after feeding with cactus cladode silage. On the other hand, no clear effect of algal supplements on C12:0 was observed (Table 2). Similar findings were also noted for C14:0 and C16:0 FAs, resulting in a high content of SFAs in milk after feeding with tanniferous plants (except for tannin extract and black current), ranging from 70.1 to $71.8 \mathrm{~g} / 100 \mathrm{~g}$ FA. However, the highest content of SFAs in milk fat was observed after feeding with dry oregano plants, regardless of the content of EOs, due to the high content of C16:0 (Tables 2 and 3). The lowest content of SFAs was found when feeding with cactus cladode silage (53.4 g/100 g FA), followed by rumen-protected algae (55.63 g/100 g FA) [185] and camelina expeller (56.05 g/kg FA) [117] (Table 3). The highest content of MUFAs was found when feeding with camelina expeller (37.92 g/100 g FA) [117] and cactus cladode silage (36.40 g/100 g FA) [160]. A low content of MUFAs was observed after feeding with the combination of oregano plants, macroalgae Acophyllum nodosum [188], Spirulina platensis [8], and Schizochytrium spp., as reported in [86] (Table 3). Feeding all four of these feeds resulted in a lower content of oleic acid (C18:1c9), suggesting lower desaturation from C18:0 [189] (see Table 2). The highest content of PUFAs in milk fat from all reviewed feeds was found in Schizochytrium spp., at 9.82 g/100 g FA, mainly due to high contents of DHA, ALA, and LA [86]. Furthermore, camelina expellers and cactus cladode silage also seem to be efficient in increasing the PUFA content in milk (Tables 2 and 3). Moreover, rumen-protected microalgae [79], okara meal, oak tannin extract and hops have the potential to improve the PUFA content in milk. On the other hand, the response in milk PUFA levels to feeding with various algal feeds was inconsistent (compare values in Table 3), suggesting that the transfer of desirable FAs from feed into milk can be influenced by many factors, such as the composition of the basal diet and the interaction of supplements with the forage type, the inclusion level, the length of supplementation, and the response of the rumen microflora to the dietary factors applied [190]. Furthermore, in a recent study, Mavrommatis et al. [190] suggested that the transfer efficiency of DHA and DPA can be influenced by the phase of lactation. A low PUFA content in milk was found after feeding with dry oregano forage regardless of the EO content, blue lupine, some tanniferous plants (hazel and silver birch), macroalgae [188], and Spirulina platensis $[8,67]$ (see Table 3).

For the evaluation of health and technological properties of milk fat, various indices can be used (see Table 4). However, in some indices there are limitations that should be mentioned. In the case of AI, and inversely HPI, the calculation includes only selected SFAs (C12:0, C14:0 and C16:0) which were thought to be hypercholesterolaemic [31], and the sum of $\mathrm{n} 3$ and $\mathrm{n} 6$ PUFAs and MUFAs. Some dietary interventions, such as supplementing the diet with feeds rich in long-chain n3 PUFAs, inhibit the saturation of PUFAs and 
various isomers of $\mathrm{C} 18: 1$ to $\mathrm{C} 18: 0$ in the rumen, resulting in a subsequent decrease in $\mathrm{C} 18: 1 \mathrm{c} 9$, the main MUFA, in milk, which is produced during the desaturation process in the mammary gland from the above-mentioned substrate FA (C18:0) [189], and thus provides a misleading AI value. Because the usage of AI persists in recent publications, e.g., [168,189], it is necessary to interpret and evaluate AI values with regards to biohydrogenation processes in the rumen.

In the case of the $\mathrm{h} / \mathrm{H}$ ratio, the main problem is that the majority of scientific studies presenting the FA profile in milk after dietary interventions are lacking in one or more of the FAs needed for the calculation of the index. Indeed, of the feeds evaluated in the present review, only two sources contained all the data necessary for the calculation of the h/H ratio. Furthermore, compared to earlier findings [34], only two FAs, C14:0 and C16:0, have been recently thought to be hypercholesterolaemic [36].

Although the DI can be calculated from various pairs of product-FA substrates, the DI (C14) is suggested to be the best expression of SCD enzyme activity because C14:0 is almost exclusively produced during de novo synthesis in the mammary gland and C14:1c9 is almost exclusively produced during the desaturation process [191,192].

Of the feedstuffs described above, the lowest AI (1.39, Table 4) of all was observed in cactus cladodes, due to their low contents of atherogenic FAs C12:0, C14, and C16:0. Among the algal feeds, a low AI (1.90) was found in rumen-protected algae [185], suggesting that rumen-protected forms of algal supplementation can be suitable not only from the view of the modification of milk FAs, but also from the dietetic point of view, because they eliminate the negative effects of algal products on feed intake, rumen fermentation, and deteriorations in milk yield and quality $[58,183]$. On the other hand, the highest AI was observed in Spirulina platensis (6,8) [77], the macroalga Ascophyllum (4.12) [187], and Schizochytrium spp. (3.28), [86], suggesting that not all algal supplements can have a positive effect on the health parameters of milk fat. However, recent findings suggest that feeding with algal products rich in DHA can decrease the relative abundance of some bacteria in the rumen (R. flavefaciens, B. proteoclasticus, F. succinogenes, and S. bovis), whereas the relative abundance of other bacteria remained unaffected (R. albus and B. fibrisolvens) [190]. Furthemore, dietary DHA inhibits the final step in the rumen biohydrogenation process, which results in the accumulation of trans-C18:1 FAs, such as C18:1t11 and C18:1t10 [190]. The accumulated trans-C18:1 FA can inhibit specific bacteria that convert C18:1 into C18:0 [190]; thus, the content of C18:1t11 in milk can be increased, as well as the content of C18:2c9t11, which is converted from the C18:1t11 during the desaturation process in the mammary gland [189]. Elevated contents of C18:2c9t11 were also observed in our review in algal feeds that were rich in DHA. 


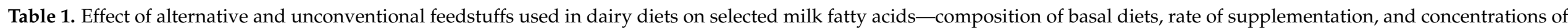
selected nutrients.

\begin{tabular}{|c|c|c|c|c|}
\hline Feed Supplement & Basal Diets & Inclusion Rate & $\begin{array}{l}\text { Concentration of Main } \\
\text { Nutrients of Interest }\end{array}$ & Source \\
\hline \multicolumn{5}{|l|}{ Macroalgae } \\
\hline Ascophyllum nodosum & $\begin{array}{l}\text { TMR based on a mixed diet-mostly grass and } \\
\text { legume baleages, soybean meal, maize, barley, } \\
\text { wheat middlings, roasted soybean }\end{array}$ & $170 \mathrm{~g} / \mathrm{d}$ (as-fed) & $\begin{array}{l}\text { NDF- } 539 \mathrm{~g} / \mathrm{kg} \mathrm{DM} \\
\text { Iodine- } 820 \mathrm{mg} / \mathrm{kg} \mathrm{DM} \\
\text { C16:0-2.73 g/kg DM } \\
\text { C18:1c9-5.59 g/kg DM } \\
\text { C18:2n6-1.48 g/kg DM }\end{array}$ & [188] \\
\hline \multicolumn{5}{|l|}{ Microalgae } \\
\hline Aurantiochytrium limacinum & $\begin{array}{l}\text { TMR based on maize silage, ryegrass, and } \\
\text { lucerne hay and concentrate containing soy } \\
\text { protein, wheat bran, dehulled sunflower meal, } \\
\text { maize meal and germs, molasses, cotton seed, } \\
\text { barley flakes, sorghum meal }\end{array}$ & $150 \mathrm{~g} / \mathrm{d}$ (as-fed) & $\mathrm{C} 22: 6 \mathrm{n} 3-160 \mathrm{~g} / \mathrm{kg}$ & [193] \\
\hline Aurantiochytrium limacinum & $\begin{array}{l}\text { TMR based on maize silage, soybean meal, } \\
\text { sunflower dehulled seed meal, maize gluten } \\
\text { meal, flaked soybean, hydrogenated palm oil, } \\
\text { maize and barley flakes, maize and sorghum } \\
\text { meals, rye grass hay, and dehydrated lucerne hay }\end{array}$ & $100 \mathrm{~g} / \mathrm{d}$ (as-fed) & $\mathrm{C} 22: 6 \mathrm{n} 3-160 \mathrm{~g} / \mathrm{kg}$ & [186] \\
\hline Schizochytrium limacinum & $\begin{array}{l}\text { TMR based on ryegrass and sorghum silages, } \\
\text { cheese whey and concentrate containing maize, } \\
\text { soybean meal, and dry distillers grains }\end{array}$ & $144 \mathrm{~g} / \mathrm{d}$ (as-fed) & $\mathrm{C} 22: 6 \mathrm{n} 3-140 \mathrm{~g} / \mathrm{kg}$ & [77] \\
\hline Schizochytrium spp. & $\begin{array}{l}\text { TMR based on maize silage, lucerne hay, cotton } \\
\text { seed, molasses and concentrate containing maize, } \\
\text { steam-flaked maize, soybean meal, cotton meal, } \\
\text { soy hulls, DDGS, and maize gluten meal }\end{array}$ & $255 \mathrm{~g} / \mathrm{d}$ (as-fed) & C22:6n3-176.4 g/kg DM & [85] \\
\hline Schizochytrium spp. & $\begin{array}{l}\text { TMR based on grass and maize silage, standard } \\
\text { concentrate and soybean meal }\end{array}$ & $43 \mathrm{~g} / \mathrm{kg}$ DM intake & $\begin{array}{l}\text { C22:6n3-198 g/kg DM } \\
(378 \mathrm{~g} / \mathrm{kg} \mathrm{FA})\end{array}$ & [187] \\
\hline Schizochytrium spp. & $\begin{array}{l}\text { diet based on grass hay and concentrate } \\
\text { containing cracked corn, soybean meal, and } \\
\text { pelleted dehydrated lucerne }\end{array}$ & $310 \mathrm{~g} / \mathrm{d}$ (as-fed) & C22:6n3-370 g/kg FA & [194] \\
\hline
\end{tabular}


Table 1. Cont.

\begin{tabular}{|c|c|c|c|c|}
\hline Feed Supplement & Basal Diets & Inclusion Rate & $\begin{array}{l}\text { Concentration of Main } \\
\text { Nutrients of Interest }\end{array}$ & Source \\
\hline Schizochytrium spp. & $\begin{array}{l}\text { diet based on lucerne hay and concentrate } \\
\text { containing wheat, cold-pressed canola meal, } \\
\text { and dry molasses }\end{array}$ & $250 \mathrm{~g} / \mathrm{d}$ (as-fed) & C22:6n3-200 g/kg DM & [86] \\
\hline Spirulina platensis & $\begin{array}{l}\text { diet based on grass silage and concentrate } \\
\text { containing sugar beet pulps and molasses }\end{array}$ & $1.12 \mathrm{~kg} \mathrm{DM} / \mathrm{d}$ & $\begin{array}{l}\text { CP-693 g/kg DM } \\
\text { C16:0-45.6 g/100 g FA } \\
\text { C18:2n6-23.4 g/100 g FA } \\
\text { C18:3n6-19.9 g/100 g FA }\end{array}$ & [67] \\
\hline Spirulina platensis & $\begin{array}{l}\text { diet based on lucerne hay, corn silage, and grain } \\
\text { mix containing wheat, maize, extracted } \\
\text { sunflower, and soybean meal and wheat bran }\end{array}$ & $150 \mathrm{~g} / \mathrm{d}$ (as-fed) & $\begin{array}{l}\text { C16:0-36.2 g/100 g FA } \\
\text { C18:2n6-26.2 g/100 g FA } \\
\text { C18:3n6-22.7 g/100 g FA }\end{array}$ & [8] \\
\hline Chlorella vulgaris & $\begin{array}{l}\text { diet based on grass silage and concentrate } \\
\text { containing sugar beet pulps and molasses }\end{array}$ & $1.35 \mathrm{~kg} \mathrm{DM} / \mathrm{d}$ & $\begin{array}{l}\text { CP-586 g/kg DM } \\
\text { C16:0-15.8 g/100 g FA } \\
\text { C18:2n6-48.5 g/100 g FA }\end{array}$ & [67] \\
\hline $\begin{array}{l}\text { Chlorella vulgaris }+ \\
\text { Nannochloropsis gaditana }\end{array}$ & $\begin{array}{l}\text { diet based on grass silage and concentrate } \\
\text { containing sugar beet pulps and molasses }\end{array}$ & 0.81 and $0.82 \mathrm{~kg} \mathrm{DM} / \mathrm{d}$, respectively & $\begin{array}{l}\mathrm{CP}-485 \mathrm{~g} / \mathrm{kg} \text { * } \\
\mathrm{C} 16: 0-20 \mathrm{~g} / 100 \mathrm{~g} \mathrm{FA} * \\
\mathrm{C} 18: 2 \mathrm{n} 6-24.9 \mathrm{~g} / 100 \mathrm{~g} \mathrm{FA} \text { * } \\
\text { C20:5n3-9.6 g/100 g FA * }\end{array}$ & [67] \\
\hline $\begin{array}{l}\text { Rumen-protected macroalgae } \\
\text { (Algamac-3050; Aquafauna } \\
\text { Bio-Marine Inc., Hawthorne, } \\
\text { CA, USA) }\end{array}$ & $\begin{array}{l}\text { TMR based on maize and grass silage, hay, barley, } \\
\text { maize distillers grain, maize, and soybean meal } \\
\text { or pasture }\end{array}$ & $\begin{array}{l}\text { calculated to provide } 200 \mathrm{~g} / \mathrm{d} \text { of total } \\
\text { lipids and cca. } 65 \mathrm{~g} / \mathrm{d} \text { LC-PUFA }\end{array}$ & $\begin{array}{l}\text { C16:0-25.02 g/100 g FA ** } \\
\text { C18:0-32.48 g/100 g FA ** } \\
\text { C22:6n3-24.23 g/100 g FA }\end{array}$ & [185] \\
\hline $\begin{array}{l}\text { Rumen-protected microalgae } \\
\text { DHA-rich microalgae protected } \\
\text { with the inert fat (not specified) }\end{array}$ & $\begin{array}{l}\text { TMR based on mixed haylage, maize silage, grass } \\
\text { hay, barley, maize, soybean meal, } \\
\text { and distillers grains }\end{array}$ & $100 \mathrm{~g} / \mathrm{d}$ (as-fed) & C22:6n3 -22.28 g/100 g FA & [79] \\
\hline
\end{tabular}


Table 1. Cont.

\begin{tabular}{|c|c|c|c|c|}
\hline Feed Supplement & Basal Diets & Inclusion Rate & $\begin{array}{l}\text { Concentration of Main } \\
\text { Nutrients of Interest }\end{array}$ & Source \\
\hline \multicolumn{5}{|l|}{ By-products } \\
\hline Okara meal & $\begin{array}{l}\text { TMR based on grass baleage, molasses, } \\
\text { maize, soyhulls }\end{array}$ & $150 \mathrm{~g} / \mathrm{kg} \mathrm{DM}$ & $\begin{array}{l}\mathrm{CP}-32.9 \mathrm{~g} / \mathrm{kg} \mathrm{DM} \\
\mathrm{EE}-10.5 \mathrm{~g} / \mathrm{kg} \mathrm{DM} \\
\mathrm{C} 18: 1 \mathrm{c} 9-19.0 \mathrm{~g} / \mathrm{kg} \mathrm{DM} \\
\mathrm{C} 18: 2 \mathrm{n} 6-58.0 \mathrm{~g} / \mathrm{kg} \mathrm{DM} \\
\mathrm{C} 18: 3 \mathrm{n} 3-10.6 \mathrm{~g} / \mathrm{kg} \mathrm{DM}\end{array}$ & [99] \\
\hline Camelina expeller & $\begin{array}{l}\text { TMR based on grass and maize silages, } \\
\text { grass hay, barley, maize gluten meal, } \\
\text { soybean meal, maize DDGS }\end{array}$ & $95 \mathrm{~g} / \mathrm{kg} \mathrm{DM}$ & $\begin{array}{l}\text { C18:1c9-131.4 mg/g FA } \\
\text { C18:2n6-223.4 mg/g FA } \\
\text { C18:3n3-319.8 mg/g FA }\end{array}$ & [117] \\
\hline Camelina expeller & $\begin{array}{l}\text { diet based on red clover silage and concentrate } \\
\text { containing barley, wheat, sugar beet pulp, } \\
\text { molasses, cereal bran, and rapeseed and } \\
\text { sunflower oil }\end{array}$ & $2.4 \mathrm{~kg} / \mathrm{d}$ (as-fed) & NA & [119] \\
\hline Camelina seeds whole & $\begin{array}{l}\text { TMR based on grass and maize silages, grass hay, } \\
\text { barley, maize gluten meal, soybean meal, } \\
\text { maize DDGS }\end{array}$ & $42 \mathrm{~g} / \mathrm{kg} \mathrm{DM}$ & $\begin{array}{l}\text { C18:1c9-121.4 mg/g FA } \\
\text { C18:2n6-185.9 mg/g FA } \\
\text { C18:3n3-367.7 mg/g FA }\end{array}$ & [117] \\
\hline \multicolumn{5}{|l|}{ Tanniferous plants } \\
\hline Oak tannin extract & $\begin{array}{l}\text { TMR based on maize and grass silages, } \\
\text { dehydrated lucerne, rapeseed meal, rolled barley, } \\
\text { sugar beet pulp, and extruded linseed }\end{array}$ & $169 \mathrm{~g} / \mathrm{kg} \mathrm{DM}$ & NA & [139] \\
\hline Hazel & \multirow{3}{*}{$\begin{array}{l}\text { for all: mixed diet based on grass and maize } \\
\text { silages, soybean meal, sugar beet pulps, and } \\
\text { pellets (lucerne + leaves of one of the } \\
\text { given plants) }\end{array}$} & \multirow{3}{*}{$\begin{array}{l}\text { calculated to reach a total extractable } \\
\text { phenol content of } 60 \mathrm{~g} / \mathrm{kg} \mathrm{DM}\end{array}$} & $\begin{array}{l}\text { C16:0-27 g/100 g FA } \\
\text { C18:1c9-16.1 g/100 g FA } \\
\text { C18:2n6-21.6 g/100 g FA } \\
\text { C18:3n3-19.2 g/100 g FA }\end{array}$ & \multirow{3}{*}{ [183] } \\
\hline Silver birch & & & $\begin{array}{l}\text { C16:0-47 g/100 g FA } \\
\text { C18:1c9-9.1 g/100 g FA }\end{array}$ & \\
\hline Black current & & & $\begin{array}{l}\text { C16:0-28.5 g/100 g FA } \\
\text { C18:2n6-14.2 g/100 g FA } \\
\text { C18:3n3-35.9 g/100 g FA }\end{array}$ & \\
\hline
\end{tabular}


Table 1. Cont.

\begin{tabular}{|c|c|c|c|c|}
\hline Feed Supplement & Basal Diets & Inclusion Rate & $\begin{array}{l}\text { Concentration of Main } \\
\text { Nutrients of Interest }\end{array}$ & Source \\
\hline Grape wine & \multirow{3}{*}{$\begin{array}{l}\text { for all: mixed diet based on grass and maize } \\
\text { silages, soybean meal, sugar beet pulps, and } \\
\text { pellets (lucerne }+ \text { leaves of one of the } \\
\text { given plants) }\end{array}$} & \multirow{3}{*}{$\begin{array}{l}\text { calculated to reach a total extractable } \\
\text { phenol content of } 60 \mathrm{~g} / \mathrm{kg} \mathrm{DM}\end{array}$} & $\begin{array}{l}\text { C16:0-30.0 g/100 g FA } \\
\text { C18:1c9-9.3 g/100 g FA } \\
\text { C18:2n6-17.9 g/100 g FA } \\
\text { C18:3n3-24.8 g/100 g FA }\end{array}$ & \multirow{3}{*}{ [183] } \\
\hline Wood avens & & & $\begin{array}{l}\text { C16:0-19.7 g/100 g FA } \\
\text { C18:1c9-19.2 g/100 g FA } \\
\text { C18:2n6-24.9 g/100 g FA } \\
\text { C18:3n3-22.5 g/100 g FA }\end{array}$ & \\
\hline Rosebay willow & & & $\begin{array}{l}\text { C16:0-26.8 g/100 g FA } \\
\text { C18:1n9-11.6 g/100 g FA } \\
\text { C18:2n6-21.3 g/100 g FA } \\
\text { C18:3n3-24.0 g/100 g FA }\end{array}$ & \\
\hline \multicolumn{5}{|l|}{ Herbs and spices } \\
\hline Hops & $\begin{array}{l}\text { TMR based on maize and grass silages, } \\
\text { dehydrated lucerne, rapeseed meal, rolled barley, } \\
\text { sugar beet pulp, and extruded linseed }\end{array}$ & $56 \mathrm{~g} / \mathrm{kg} \mathrm{DM}$ & NA & [139] \\
\hline $\begin{array}{l}\text { Oregano low in } \mathrm{EO}(0.12 \%) \\
\text { (Origanum vulgare ssp. vulgare) }\end{array}$ & $\begin{array}{l}\text { TMR based on clover-grass and maize silages } \\
\text { and concentrates }\end{array}$ & $53 \mathrm{~g} / \mathrm{kg} \mathrm{DM}$ & $\begin{array}{l}\text { Carvacrol- } 31.1 \% \text { of total EO } \\
\text { Thymol- } 22.7 \% \text { of total EO }\end{array}$ & [148] \\
\hline $\begin{array}{l}\text { Oregano high in } \mathrm{EO}(4.21 \%) \\
\text { (Origanum vulgare ssp. hirtum) }\end{array}$ & $\begin{array}{l}\text { TMR based on clover-grass and maize silages } \\
\text { and concentrates }\end{array}$ & $21 \mathrm{~g} / \mathrm{kg} \mathrm{DM}$ & $\begin{array}{l}\text { Carvacrol }-35 \% \text { of total EO } \\
\text { Thymol }-41 \% \text { of total EO }\end{array}$ & [148] \\
\hline \multicolumn{5}{|l|}{ Others } \\
\hline Cactus cladode silage & $\begin{array}{l}\text { TMR based on sorghum silage, maize, and } \\
\text { soybean meal and oil }\end{array}$ & $340 \mathrm{~g} / \mathrm{kg} \mathrm{DM}$ & $\begin{array}{l}\text { C16:0-27.8 g/100 g FA } \\
\text { C18:2n6-31.7 g/100 g FA } \\
\text { C18:3n3-16.5 g/100 g FA }\end{array}$ & [160] \\
\hline Blue lupin & $\begin{array}{l}\text { TMR based on grass and maize silage, beet pulp, } \\
\text { brewers grains, wheat, extracted rapeseed, } \\
\text { and soybean meal }\end{array}$ & $94 \mathrm{~g} / \mathrm{kg} \mathrm{DM}$ & $\begin{array}{l}\text { CP-345 g/kg DM } \\
\text { C16:0-11.2 g/100 g FA } \\
\text { C18:1c9-26.5 g/100 g FA } \\
\text { C18:2n6-31.8 g/100 g FA } \\
\text { C18:3n3-6.58 g/100 g FA }\end{array}$ & [168] \\
\hline
\end{tabular}

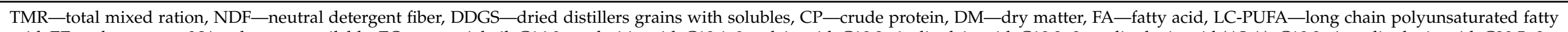

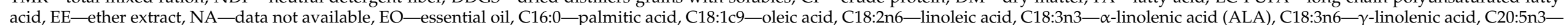

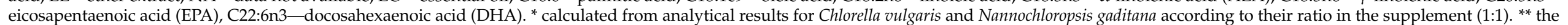
high content of saturated FA probably comes from the coating (non-specified inert fat). 
Table 2. Effect of alternative and unconventional feedstuffs used in dairy diets on selected milk fatty acids (g/100 g FA).

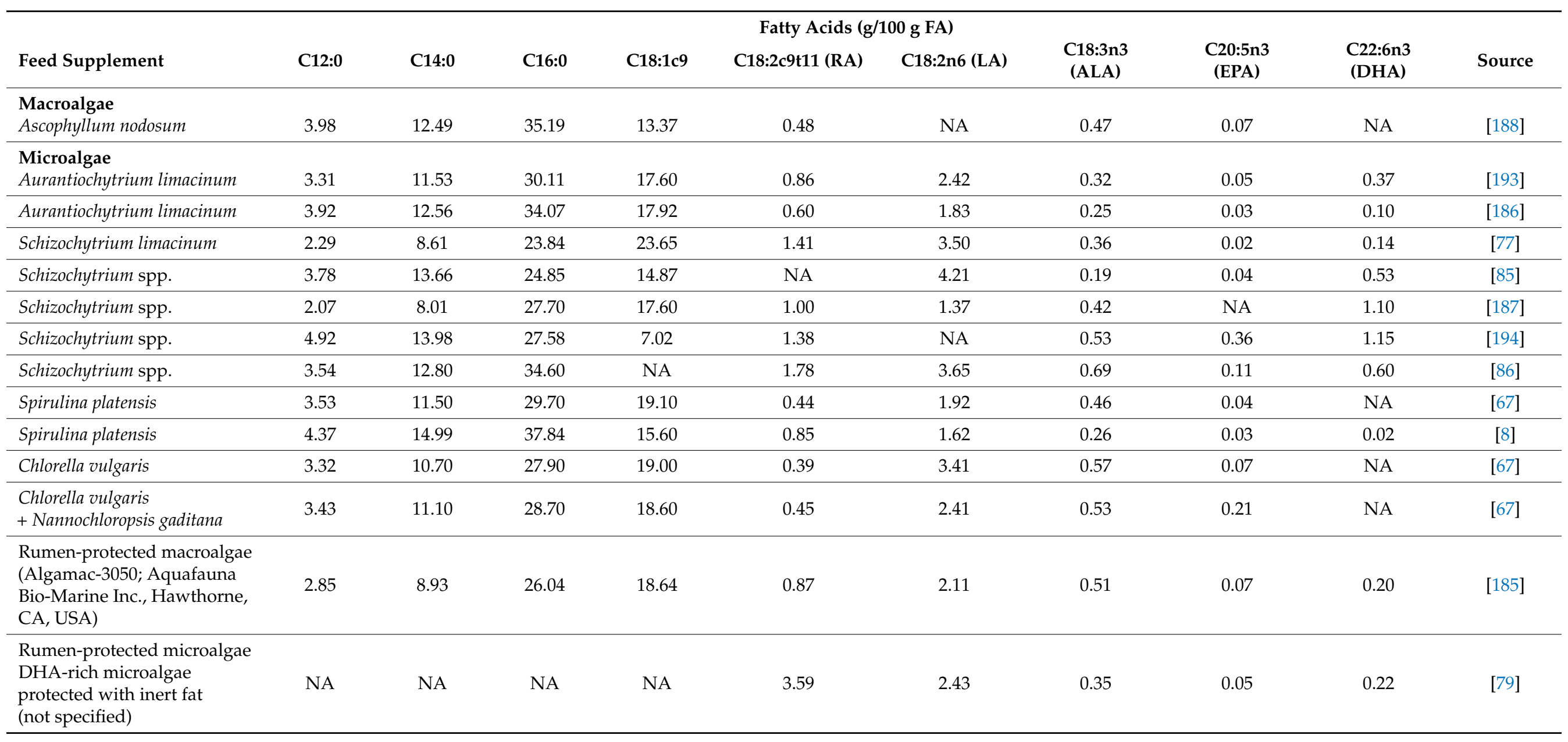


Table 2. Cont

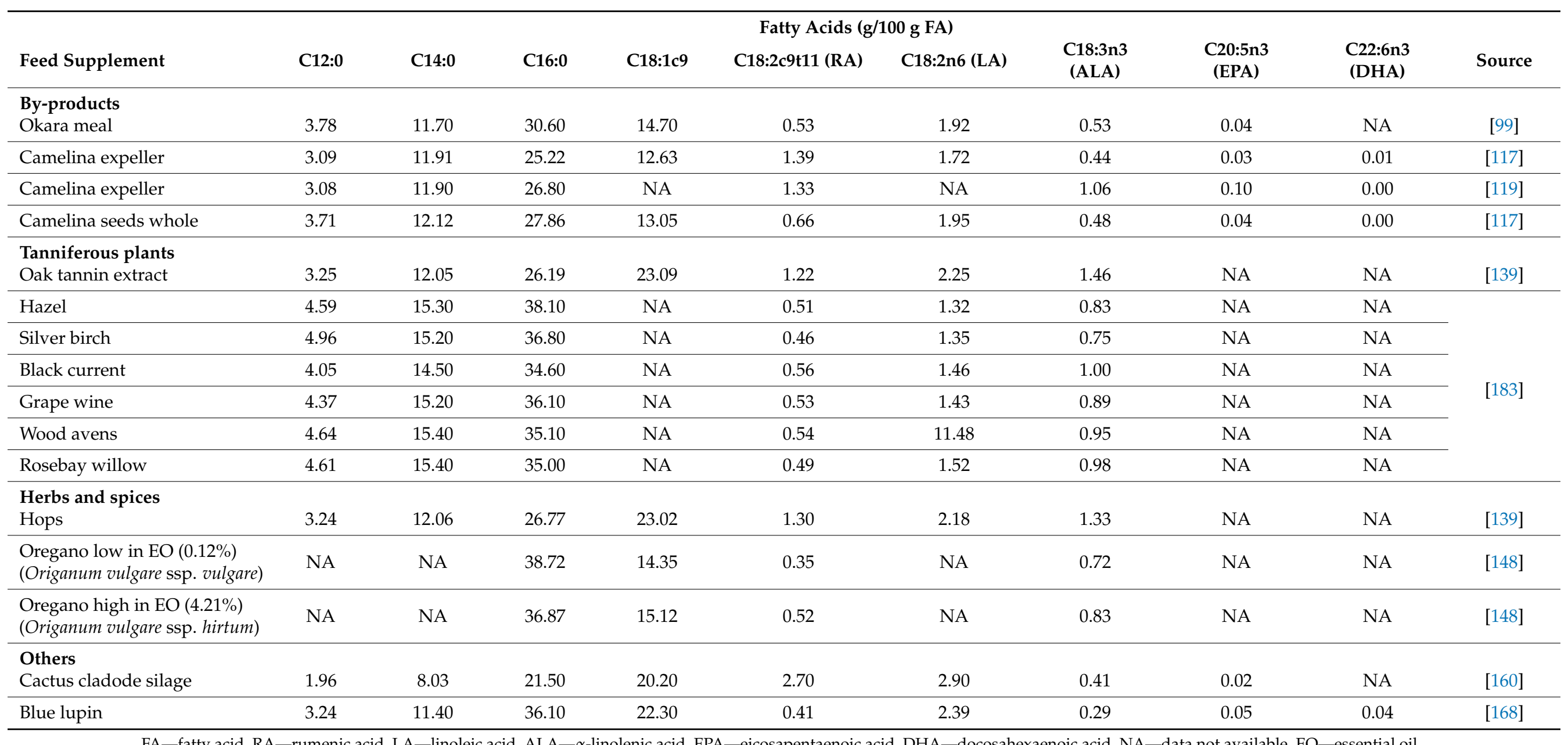

FA—fatty acid, RA—rumenic acid, LA—linoleic acid, ALA— $\alpha$-linolenic acid, EPA—eicosapentaenoic acid, DHA—docosahexaenoic acid, NA—data not available, EO—essential oil. 
Table 3. Effect of alternative and unconventional feedstuffs used in dairy diets on selected sums of milk fatty acids (g/100 g FA).

\begin{tabular}{|c|c|c|c|c|c|c|c|}
\hline \multirow[b]{2}{*}{ Feed Supplement } & \multirow[b]{2}{*}{ n6 } & \multirow[b]{2}{*}{ n3 } & \multicolumn{2}{|c|}{ Sums of FA (g/100g) } & \multirow[b]{2}{*}{ MUFA } & \multirow[b]{2}{*}{ PUFA } & \multirow[b]{2}{*}{ Source } \\
\hline & & & n6/n3 & SFA & & & \\
\hline $\begin{array}{l}\text { Macroalgae } \\
\text { Ascophyllum nodosum }\end{array}$ & 1.85 & 0.59 & 3.14 & 74.93 & 19.19 & 3.35 & [188] \\
\hline $\begin{array}{l}\text { Microalgae } \\
\text { Aurantiochytrium limacinum }\end{array}$ & 2.54 & 0.90 & 2.82 & 67.82 & 27.86 & 4.32 & [193] \\
\hline Aurantiochytrium limacinum & 1.96 & 0.50 & 3.92 & 72.62 & 24.20 & 3.04 & [186] \\
\hline Schizochytrium limacinum & NA & NA & 6.78 & 54.92 & 36.44 & 6.05 & [77] \\
\hline Schizochytrium spp. & 4.56 & 0.83 & 5.49 & 70.95 & 23.54 & 5.51 & [85] \\
\hline Schizochytrium spp. & 1.38 & 1.54 & 0.89 & 53.90 & 33.60 & 4.70 & [187] \\
\hline Schizochytrium spp. & NA & NA & NA & NA & NA & 4.61 & [194] \\
\hline Schizochytrium spp. & 5.92 & 1.69 & 3.50 & 70.60 & 19.60 & 9.82 & [86] \\
\hline Spirulina platensis & 2.20 & 0.56 & 4.06 & 70.30 & 25.50 & 3.30 & {$[67]$} \\
\hline Spirulina platensis & 1.85 & 0.56 & 3.36 & 74.34 & 18.61 & 3.25 & [8] \\
\hline Chlorella vulgaris & 3.68 & 0.71 & 5.43 & 68.20 & 25.50 & 4.85 & [67] \\
\hline $\begin{array}{l}\text { Rumen-protected macroalgae } \\
\text { (Algamac-3050; Aquafauna Bio-Marine Inc., } \\
\text { Hawthorne, CA, USA) }\end{array}$ & 3.67 & 0.94 & 3.99 & 55.63 & 29.31 & 4.61 & [185] \\
\hline $\begin{array}{l}\text { Rumen-protected microalgae } \\
\text { DHA-rich microalgae protected with the inert } \\
\text { fat (not specified) }\end{array}$ & 4.56 & 0.83 & 5.49 & 61.90 & 31.21 & 5.45 & [79] \\
\hline $\begin{array}{l}\text { By-products } \\
\text { Okara meal }\end{array}$ & 2.07 & 0.63 & 3.26 & 72.69 & 22.11 & 5.19 & [99] \\
\hline Camelina expeller & 2.00 & 0.48 & 0.45 & 56.05 & 37.92 & 6.02 & [117] \\
\hline Camelina expeller & NA & 1.40 & NA & 62.60 & 29.70 & 7.27 & [119] \\
\hline Camelina seeds whole & 2.25 & 0.62 & 0.39 & 62.89 & 32.48 & 4.63 & [117] \\
\hline
\end{tabular}


Table 3. Cont

\begin{tabular}{|c|c|c|c|c|c|c|c|}
\hline \multirow[b]{2}{*}{ Feed Supplement } & \multirow[b]{2}{*}{ n6 } & \multirow[b]{2}{*}{ n3 } & \multicolumn{2}{|c|}{ Sums of FA (g/100g) } & \multirow[b]{2}{*}{ MUFA } & \multirow[b]{2}{*}{ PUFA } & \multirow[b]{2}{*}{ Source } \\
\hline & & & n6/n3 & SFA & & & \\
\hline \multicolumn{8}{|l|}{ Tanniferous plants } \\
\hline Oak tannin & NA & NA & NA & 64.23 & 30.46 & 5.31 & [139] \\
\hline Hazel & 1.62 & 0.99 & 1.64 & 71.80 & 23.10 & 3.76 & \multirow{5}{*}{ [183] } \\
\hline Silver birch & 1.67 & 0.95 & 1.77 & 71.80 & 23.20 & 3.62 & \\
\hline Black current & 1.76 & 1.12 & 1.48 & 68.00 & 26.40 & 4.17 & \\
\hline Wood avens & 1.86 & 1.14 & 1.64 & 70.10 & 24.40 & 4.15 & \\
\hline Rosebay willow & 1.85 & 1.17 & 1.59 & 70.40 & 24.10 & 4.11 & \\
\hline \multicolumn{8}{|l|}{ Herbs and spices } \\
\hline Hops & NA & NA & NA & 64.09 & 30.71 & 5.20 & [139] \\
\hline $\begin{array}{l}\text { Oregano low in EO }(0.12 \%) \\
\text { (Origanum vulgare ssp. vulgare) }\end{array}$ & NA & NA & NA & 78.60 & 18.34 & 3.06 & [148] \\
\hline $\begin{array}{l}\text { Oregano high in EO }(4.21 \%) \\
\text { (Origanum vulgare ssp. hirtum) }\end{array}$ & NA & NA & NA & 77.04 & 19.76 & 3.20 & [148] \\
\hline \multicolumn{8}{|l|}{ Others } \\
\hline Cactus cladode silage & 3.14 & 0.46 & 6.83 & 53.40 & 36.40 & 6.70 & [160] \\
\hline Blue lupin & 5.22 & 0.47 & 11.20 & 67.90 & 28.50 & 3.56 & [168] \\
\hline
\end{tabular}

SFA—saturated fatty acid, MUFA—monounsaturated fatty acid, PUFA—polyunsaturated fatty acid, NA—data not available, EO—essential oil. 
Table 4. Main effects of alternative and unconventional feedstuffs used in dairy diets on indices characterizing health and technological properties of milk fat.

\begin{tabular}{|c|c|c|c|c|c|c|c|}
\hline Feed Supplement & AI & HPI & $\begin{array}{l}\text { Indic } \\
\text { S/P }\end{array}$ & DI & SI & Main Effect & Source \\
\hline \multicolumn{8}{|l|}{ Macroalgae } \\
\hline Ascophyllum nodosum & 4.12 & 0.25 & 2.53 & $57.38(\mathrm{C} 18)$ & NA & $\begin{array}{l}\text { minor changes in isoC14:0, C15:0, C14:1t4, } \\
\mathrm{C} 18: 1 \mathrm{c} 11, \mathrm{C} 20: 1 \mathrm{c} 11, \mathrm{C} 22: 4 \mathrm{c} 7 \mathrm{c} 10 \mathrm{c} 13 \mathrm{c} 16\end{array}$ & [188] \\
\hline $\begin{array}{l}\text { Microalgae } \\
\text { Aurantiochytrium limacinum }\end{array}$ & 2.54 & 0.40 & 1.60 & 7.78 & 0.53 & \multirow{2}{*}{$\begin{array}{ll} & \text { decrease in SFA, C16:0, C20:3n3, n6/n3 } \\
\text { - } & \text { increase in PUFA, n-3 FA, C18:1 t11, } \\
\text { C18:2c9t11, C20:5n-3; C22:6n-3 }\end{array}$} & [193] \\
\hline Aurantiochytrium limacinum & 3.31 & 0.31 & 2.03 & 7.39 & 0.58 & & [186] \\
\hline Schizochytrium spp. & 2.88 & 0.35 & 1.67 & 8.51 & 0.60 & \multirow{4}{*}{$\begin{array}{l}\text { decrease in C12:0-C16:0, C18:0, and n6/n3 } \\
\text { increase in C18:1t, CLA, C18:3n3, } \\
\text { C20:5n3, C22:6n3 }\end{array}$} & [85] \\
\hline Schizochytrium spp. & 1.69 & 0.62 & 1.03 & 6.43 & 0.64 & & [187] \\
\hline Schizochytrium spp. & NA & NA & NA & 8.15 & 0.25 & & [194] \\
\hline Schizochytrium spp. & 3.28 & 0.33 & 1.68 & 8.44 & NA & & [86] \\
\hline Spirulina platensis & 2.80 & 0.36 & 1.81 & 7.30 & 0.64 & $\begin{array}{l}\text { - incease in C18:3n3, C18:3c6c9c12, } \\
\text { and PUFA }\end{array}$ & {$[67]$} \\
\hline Chlorella vulgaris & 2.48 & 0.41 & 1.66 & 6.56 & 0.68 & $\begin{array}{l}\text { - } \quad \text { increase in C20:5n3, C18:3n3, C18:3c6c9c12, } \\
\text { and PUFA }\end{array}$ & [67] \\
\hline $\begin{array}{l}\text { Chlorella vulgaris }+ \\
\text { Nannochloropsis gaditana }\end{array}$ & 2.60 & 0.39 & 1.69 & 7.28 & 0.65 & $\begin{array}{l}\text { - increase in C20:5n3, C18:3n3, } \\
\text { C18:3c6c9c12, and PUFA } \\
\text { - } \quad \text { decrease in } n 6 / n 3\end{array}$ & [67] \\
\hline $\begin{array}{l}\text { Rumen-protected macroalgae } \\
\text { (Algamac-3050; Aquafauna } \\
\text { Bio-Marine Inc., Hawthorne, } \\
\text { CA, USA) }\end{array}$ & 1.90 & 0.52 & 1.32 & 10.43 & 0.72 & $\begin{array}{ll}\text { - } & \text { decrease in C16:0 and SFA } \\
\text { - } & \text { increase in CLA, n3 LC-PUFA, } \\
& \text { trans 18:1, C18:3n3, C22:6n3 }\end{array}$ & [185] \\
\hline $\begin{array}{l}\text { Rumen-protected } \\
\text { microalgae-DHA-rich } \\
\text { microalgae protected with the } \\
\text { inert fat (not specified) }\end{array}$ & NA & NA & NA & NA & NA & & [79] \\
\hline
\end{tabular}


Table 4. Cont.

\begin{tabular}{|c|c|c|c|c|c|c|c|}
\hline Feed Supplement & AI & HPI & $\begin{array}{l}\text { Indices } \\
\mathrm{S} / \mathrm{P}\end{array}$ & DI & SI & Main Effect & Source \\
\hline \multicolumn{8}{|l|}{ By-products } \\
\hline Okara meal & 3.27 & 0.34 & 2.02 & 6.25 & 0.48 & $\begin{array}{l}\text { - } \quad \text { increase in C18:1t10, C18:1t11, C18:2c9,t11, } \\
\text { n-6 FAs, and total n3 FAs } \\
\text { decrease in total odd-chain FAs } \\
\text { and de novo FAs }\end{array}$ & [99] \\
\hline Camelina expeller & 1.88 & 0.58 & 0.99 & 12.16 & 0.50 & \multirow{2}{*}{$\begin{array}{l}\text { - } \quad \text { decrease in C18:0, C18:1c9, } \\
\text { and several n6 FAs } \\
\text { increase in n9 MUFAs (except C18:1c9) } \\
\text { and long-chain n6 FAs (20:2c11c14 and } \\
\text { C22:2c13c16) }\end{array}$} & [117] \\
\hline Camelina expeller & NA & 0.48 & 1.25 & 7.68 & NA & & [119] \\
\hline Camelina seeds whole & 2.26 & 0.46 & 1.29 & 9.00 & 0.47 & 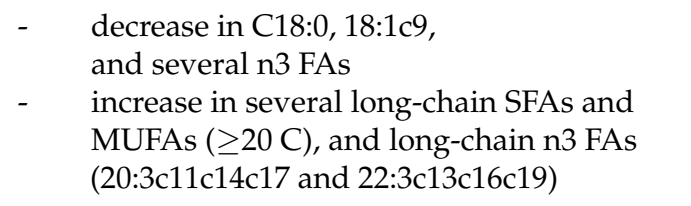 & [117] \\
\hline Oak tannin extracts & 2.55 & 0.46 & 1.47 & 7.87 & 0.88 & $\begin{array}{ll}\text { - } & \text { increase in } \mathrm{C} 18: 3 \mathrm{n} 3 \\
\text { - } & \text { decreased C18:2n6:C18:3n3 ratio }\end{array}$ & [139] \\
\hline Hazel & 4.04 & 0.26 & 2.20 & 38.64 (RA) & NA & $\begin{array}{ll}\text { - } & \text { increase in C16:0 } \\
\text { - } & \text { decrease in C18:2c9t11, C15.0, C15:1, C16:1, } \\
& \text { iso C17, PUFAs }\end{array}$ & [183] \\
\hline Silver birch & 3.97 & 0.26 & 2.17 & $\begin{array}{l}38.33 \\
(\mathrm{RA})\end{array}$ & NA & $\begin{array}{l}\text { - } \quad \text { decrease in C18:2c9t11, C15:1, C16:1, } \\
\text { iso C17, PUFAs }\end{array}$ & [183] \\
\hline Black current & 3.30 & 0.32 & 1.84 & $\begin{array}{l}35.90 \\
\text { (RA) }\end{array}$ & NA & $\begin{array}{ll}\text { - } & \text { increase in C18:1c11 } \\
\text { - } & \text { decrease in C15.0, C15:1, C16:1, iso C17 }\end{array}$ & [183] \\
\hline
\end{tabular}


Table 4. Cont.

\begin{tabular}{|c|c|c|c|c|c|c|c|}
\hline Feed Supplement & AI & HPI & $\begin{array}{l}\text { Indi } \\
\text { S/P }\end{array}$ & DI & SI & Main Effect & Source \\
\hline Grape wine & 3.76 & 0.28 & 2.03 & 50.00 (RA) & NA & $\begin{array}{l}\text { - } \quad \text { decrease in C18:2c9t11, C15.0, C15:1, } \\
\text { C16:1, iso C17 }\end{array}$ & [183] \\
\hline Wood avens & 3.70 & 0.28 & 2.00 & $\begin{array}{l}38.57 \\
(\mathrm{RA})\end{array}$ & NA & $\begin{array}{l}\text { - } \quad \text { decrease in C18:2c9t11, C15.0, C15:1, } \\
\text { C16:1, iso C17 }\end{array}$ & [183] \\
\hline Rosebay willow & 3.73 & 0.28 & 2.04 & $\begin{array}{l}36.57 \\
\text { (RA) }\end{array}$ & NA & decrease in $\mathrm{C} 18: 2 \mathrm{c} 9 \mathrm{t} 11$ & [183] \\
\hline \multicolumn{8}{|l|}{ Herbs and spices } \\
\hline Hops & 2.55 & 0.46 & 1.47 & 8.08 & 0.86 & no effect on milk FAs & [139] \\
\hline $\begin{array}{l}\text { Oregano low in } \mathrm{EO}(0.12 \%) \\
\text { (Origanum vulgare ssp. vulgare) }\end{array}$ & 2.11 & 0.55 & 2.09 & $\begin{array}{l}70.35 \\
(\mathrm{C} 18)\end{array}$ & 0.37 & - $\quad$ increase in C18:3n3 & [148] \\
\hline $\begin{array}{l}\text { Oregano high in } \mathrm{EO}(4.21 \%) \\
\text { (Origanum vulgare ssp. hirtum) }\end{array}$ & 1.87 & 0.62 & 1.90 & 69.16 (C18) & 0.41 & no effect on FAs & [148] \\
\hline Cactus cladode silage & 1.39 & 0.78 & 1.04 & 6.51 & 0.94 & $\begin{array}{l}\text { - } \quad \text { increase in 18:1 } \mathrm{t} 11,18: 2 \mathrm{n} 6 \\
\text { 18:3n3, C18:2c9t11 } \\
\text { - } \quad \text { decrease in C18:0 and 18:1c9 }\end{array}$ & [160] \\
\hline Blue lupin & 2.66 & 0.38 & 1.80 & 9.88 & 0.62 & $\begin{array}{ll}\text { - } & \text { increase in UFAs and MUFAs } \\
\text { - } & \text { decrease in SFAs and n6/n3 }\end{array}$ & [168] \\
\hline
\end{tabular}

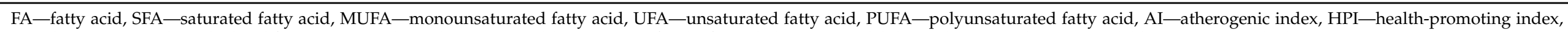

DI—desaturation index calculated from C14 FA unless otherwise noted (see Section 2 for the formulas), SI—spreadability index, NA—data not available, EO-essential oil. 


\section{Conclusions}

The demand for high quality milk is constantly growing. Studies in the area of milk fat have focused mainly on ways to increase the content of polyunsaturated and $\mathrm{n} 3$ fatty acids and to improve the $\mathrm{n} 6 / \mathrm{n} 3$ ratio. Aside from the thoroughly-studied dietary factors and common feedstuffs, there are also some alternative or unconventional feedstuffs that are often used for different purposes (e.g., for the reduction of methane emissions), which may modify the FA profile of milk fat. However, the effects of various feedstuffs on milk fatty acid profiles are difficult to compare due to the large spectrum of individual FAs that should be taken into consideration and due to differences in the applied dietary factors, such as the kind of feedstuff and its proportion/amount in the diet, the composition of the basal diet, as well as the nature of the supplements and the length of supplementation. Thus, using indices characterizing the health properties of milk fat can be helpful.

Author Contributions: Conceptualization, L.K. and S.H.; writing-original draft preparation, S.H., L.K., K.S. and S.M.; writing-review and editing, L.K., K.S., S.H. and S.M.; supervision, L.K. and S.H.; project administration, L.K. and S.H.; funding acquisition, L.K. and S.H. All authors have read and agreed to the published version of the manuscript.

Funding: This work was funded by the Ministry of Agriculture of the Czech Republic, institutional support MZE-RO1218, and by the Ministry of Education Youth and Sports of the Czech Republic, grant number MSM 6215712402.

Institutional Review Board Statement: Not applicable.

Data Availability Statement: No new data were created or analyzed in this study. Data sharing is not applicable to this article.

Conflicts of Interest: The authors declare no conflict of interest.

\section{References}

1. OECD/FAO. OECD-FAO Agricultural Outlook 2020-2029; OECD Publishing: Paris, France; FAO: Rome, Italy, 2020. [CrossRef]

2. EC (2020), Short-Term Outlook for EU Agricultural Markets in 2020. European Commission, DG Agriculture and Rural Development, Brussels. Available online: https:/ / ec.europa.eu/info/sites/info/files/food-farming-fisheries/farming/documents/shortterm-outlook-summer-2020_en.pdf (accessed on 15 May 2021).

3. Hanuš, O.; Samková, E.; Kř́žzoá, L.; Hasoňová, L.; Kala, R. Role of fatty acids in milk fat and the influence of selected factors on their variability-A review. Molecules 2018, 23, 1636. [CrossRef]

4. Simopoulos, A.P. The importance of the ratio of omega-6/omega-3 essential fatty acids. Biomed. Pharmacother. 2002, 56, 365-379. [CrossRef]

5. Moallem, U. Invited review: Roles of dietary n-3 fatty acids in performance, milk fat composition, and reproductive and immune systems in dairy cattle. J. Dairy Sci. 2018, 101, 8641-8661. [CrossRef]

6. Kumari, P.; Kumar, M.; Gupta, V.; Reddy, C.R.K.; Jha, B. Tropical marine macroalgae as potential sources of nutritionally important PUFAs. Food Chem. 2010, 120, 740-757. [CrossRef]

7. Hadrová, S.; Veselý, A.; Křižová, L. Assesment of bovine milk fat quality from the view of human health. In New Traits and Adding Value to the Recording and ID Services in the Animal Production, Proceedings of the 43rd ICAR Conference, Prague, Czech Republic, 17-21 June 2019; Prague, J., Kucera, P., Bucek, D., Lipovsky, X., Bourrigan Burke, M., Eds.; ICAR: Rome, Italy, 2019; Volume 24, pp. 217-221, ISBN 92-95014-20-0.

8. Póti, P.; Pajor, F.; Bodnár, Á.; Penksza, K.; Köles, P. Effect of micro-alga supplementation on goat and cow milk fatty acid composition. Chil. J. Agric. Res. 2015, 75, 259-263. [CrossRef]

9. Bobe, G.; Zimmerman, S.; Hammond, E.G.; Freeman, A.E.; Porter, P.A.; Luhman, C.M.; Beitz, D.C. Butter composition and texture from cows with different milk fatty acid compositions fed fish oil or roasted soybeans. J. Dairy Sci. 2007, 90, 2596-2603. [CrossRef]

10. EFSA panel on dietetic products, nutrition and allergies (NDA); Scientific opinion related to the tolerable upper intake level of eicosapentaenoic acid (EPA), docosahexaenoic acid (DHA) and docosapentaenoic acid (DPA). EFSA J. 2012, 10, 2815. Available online: www.efsa.europa.eu/efsajournal (accessed on 12 March 2021).

11. Nguyen, Q.V.; Malau-Aduli, B.S.; Cavalieri, J.; Malau-Aduli, A.E.O.; Nichols, P.D. Enhancing omega-3 long-chain polyunsaturated fatty acid content of dairy-derived foods for human consumption. Nutrients 2019, 11, 743. [CrossRef] [PubMed]

12. Bárcenas-Pérez, D.; Lukeš, M.; Hrouzek, P.; Kubáč, D.; Kopecký, J.; Kaštánek, P.; Cheel, J. A biorefinery approach to obtain docosahexaenoic acid and docosapentaenoic acid n-6 from Schizochytrium using high performance countercurrent chromatography. Algal Res. 2021, 55, 102241. [CrossRef] 
13. Rymer, C.; Givens, D.I.; Wahle, K.W.J. Dietary strategies for increasing docosahexaenoic acid (DHA) and eicosapentaenoic acid (EPA) concentrations in bovine milk: A review. In Nutrition Abstracts and Reviews. Series B: Livestock Feeds and Feeding; CAB International: Wallingford, UK, 2003; Volume 73, ISSN 0309-135X.

14. Simopoulos, A.P. An increase in the omega-6/omega-3 fatty acid ratio increases the risk for obesity. Nutrients 2016, 8, 128. [CrossRef] [PubMed]

15. Swanson, D.; Block, R.; Mousa, S.A. Omega-3 fatty acids EPA and DHA: Health benefits throughout life. Adv. Nutr. 2012, 3, 1-7. [CrossRef]

16. Neff, L.M.; Culiner, J.; Cunningham-Rundles, S.; Seidman, C.; Meehan, D.; Maturi, J.; Wittkowski, K.M.; Levine, B.; Breslow, J.L. Algal docosahexaenoic acid affects plasma lipoprotein particle size distribution in overweight and obese adults. J. Nutr. 2011, 141, 207-213. [CrossRef]

17. Lopes da Silva, T.; Moniz, P.; Silva, C.; Reis, A. The dark side of microalgae biotechnology: A heterotrophic biorefinery platform directed to $\omega$-3 rich lipid production. Microorganisms 2019, 7, 670. [CrossRef]

18. Peltomaa, E.; Johnson, M.D.; Taipale, S.J. Marine cryptophytes are great sources of EPA and DHA. Mar. Drugs 2017, 16, 3. [CrossRef]

19. Markiewicz-Kęszycka, M.; Czyżak-Runowska, G.; Lipińska, P.; Wójtowski, J. Fatty acid profile of milk-A review. Bull. Vet. Inst. Pulawy 2013, 57, 135-139. [CrossRef]

20. Calder, P.C. Very long-chain n-3 fatty acids and human health: Fact, fiction and the future. Proc. Nutr. Soc. 2018, 77, 52-72. [CrossRef]

21. Shahidi, F.; Ambigaipalan, P. Omega-3 polyunsaturated fatty acids and their health benefits. Annu. Rev. Food Sci. Technol. 2018, 9, 345-381. [CrossRef]

22. Calder, P.C. Very long chain omega-3 (n-3) fatty acids and human health. Eur. J. Lipid. Sci. Technol. 2014, 116, 1280-1300. [CrossRef]

23. Lordan, S.; Ross, R.P.; Stanton, C. Marine bioactives as functional food ingredients: Potential to reduce the incidence of chronic diseases. Mar. Drugs 2011, 9, 1056-1100. [CrossRef]

24. Szabó, Z.; Marosvölgyi, T.; Szabó, É.; Bai, P.; Figler, M.; Verzár, Z. The potential beneficial effect of EPA and DHA supplementation managing cytokine storm in coronavirus disease. Front. Physiol. 2020, 11, 752. [CrossRef]

25. Nguyen, D.V.; Malau-Aduli, B.S.; Cavalieri, J.; Nichols, P.D.; Malau-Aduli, A.E.O. Supplementation with plant-derived oils rich in omega-3 polyunsaturated fatty acids for lamb production. Vet. Anim. Sci. 2018, 6, 29-40. [CrossRef]

26. Lee, J.M.; Lee, H.; Kang, S.; Park, W.J. Fatty acid desaturases, polyunsaturated fatty acid regulation, and biotechnological advances. Nutrients 2016, 8, 23. [CrossRef]

27. Sergeant, S.; Rahbar, E.; Chilton, F.H. Gamma-linolenic acid, dihommo-gamma linolenic, eicosanoids and inflammatory processes. Eur. J. Pharmacol. 2016, 785, 77-86. [CrossRef]

28. Białek, M.; Czauderna, M.; Białek, A. Conjugated linolenic acid (CLnA) isomers as new bioactive lipid compounds in ruminantderived food products. A review. J. Anim. Feed. Sci. 2017, 26, 354-358. [CrossRef]

29. Belury, M.A. Inhibition of carcinogenesis by conjugated linoleic acid: Potential mechanisms of action. J. Nutr. 2002, 132, 2995-2998. [CrossRef] [PubMed]

30. Vargas-Bello-Pérez, E.; Márquez-Hernández, R.I.; Hernández-Castellano, L.E. Bioactive peptides from milk: Animal determinants and their implications in human health. J. Dairy Res. 2019, 86, 136-144. [CrossRef] [PubMed]

31. Haug, A.; Hostmark, A.T.; Harstad, O.M. Bovine milk in human nutrition: A review. Lipids Health Dis. 2007, 6, 25. [CrossRef]

32. Breslow, J.L. N-3 fatty acids and cardiovascular disease. Am. J. Clin. Nutr. 2006, 83, 1477S-1482S. [CrossRef]

33. Simopoulos, A.P. Omega-6/Omega-3 essential fatty acid ratio and chronic diseases. Food Rev. Int. 2004, 20, 77-90. [CrossRef]

34. Ulbricht, T.L.; Southgate, D.A. Coronary heart disease-7 dietary factors. Lancet 1991, 338, 985-992. [CrossRef]

35. Chen, S.; Bobe, G.; Zimmerman, S.; Hammond, E.G.; Luhman, C.M.; Boylston, T.D.; Freeman, A.E.; Beitz, D.C. Physical and sensory properties of dairy products from cows with various milk fatty acid compositions. J. Agric. Food Chem. 2004, 52, 3422-3428. [CrossRef]

36. Santos-Silva, J.; Bessa, R.J.B.; Santos-Silva, F. Effect of genotype, feeding system and slaughter weight on the quality of light lambs-2. Fatty acid composition of meat. Livest. Prod. Sci. 2002, 77, 187-194. [CrossRef]

37. Bobe, G.; Zimmerman, S.; Hammond, E.G.; Freeman, A.E.G.; Lindberg, G.L.; Beitz, D.C. Texture of butters made from milks differing in indices of atherogenicity. Iowa State Univ. Anim. Ind. Rep. 2004, 650, 1-3. Available online: http:/ /lib.dr.iastate.edu/ ans_air/vol650/iss1/61 (accessed on 1 March 2021). [CrossRef]

38. Rafiee-Yarandi, H.; Ghorbani, G.R.; Alikhani, M.; Sadeghi-Sefidmazgi, A.; Drackley, J.K. A comparison of the effect of soybeans roasted at different temperatures versus calcium salts of fatty acids on performance and milk fatty acid composition of midlactation HolsteiCn cows. J. Dairy Sci. 2016, 99, 5422-5435. [CrossRef]

39. Timmen, H. Characterization of milk fat hardness in farm milk via parameters of fatty-acid composition. Kieler Milchw. Forsch. 1990, 42, 129-138.

40. Kelsey, J.A.; Corl, B.A.; Collier, R.J.; Bauman, D.E. The effect of breed, parity, and stage of lactation on conjugated linoleic acid (CLA) in milk fat from dairy cows. J. Dairy Sci. 2003, 86, 2588-2597. [CrossRef]

41. Khan, M.I.; Shin, J.H.; Kim, J.D. The promising future of microalgae: Current status, challenges, and optimization of a sustainable and renewable industry for biofuels, feed, and other products. Microb. Cell Fact. 2018, 17, 36. [CrossRef] [PubMed] 
42. Khan, M.; Karmakar, R.; Das, B.; Diba, F.; Razu, M.H. Heterotrophic growth of micro algae. In Recent Advances in Microalgal Biotechnology; Liu, J., Zheng, S., Henri, G., Eds.; OMICS Group eBooks: Hyderabad, India, 2016; pp. 1-18.

43. Makkar, H.P.S.; Tran, G.; Heuzé, V.; Giger-Reverdin, S.; Lessire, M.; Lebas, F.; Ankers, P. Seaweeds for livestock diets: A review. Anim. Feed Sci. Technol. 2016, 212, 1-17. [CrossRef]

44. Morais, T.; Inácio, A.; Coutinho, T.; Ministro, M.; Cotas, J.; Pereira, L.; Bahcevandziev, K. Seaweed potential in the animal feed: A review. J. Mar. Sci. Eng. 2020, 8, 559. [CrossRef]

45. Wang, S.-H.; Huang, C.-Y.; Chen, C.-Y.; Chang, C.-C.; Huang, C.-Y.; Dong, C.-D.; Chang, J.-S. Structure and biological activity analysis of fucoidan isolated from Sargassum siliquosum. ACS Omega 2020, 5, 32447-32455. [CrossRef]

46. Devillé, C.; Gharbi, M.; Dandrifosse, G.; Peulen, O. Study on the effects of laminarin, a polysaccharide from seaweed, on gut characteristics. J. Sci. Food Agric. 2007, 87, 1717-1725. [CrossRef]

47. Alves, A.; Sousa, R.A.; Reis, R.L. A practical perspective on ulvan extracted from green algae. J. Appl. Phycol. 2013, 25, 407-424. [CrossRef]

48. Dawczynski, C.; Schubert, R.; Jahreis, G. Amino acids, fatty acids, and dietary fibre in edible seaweed products. Food Chem. 2007, 103, 891-899. [CrossRef]

49. Neville, E.W.; Fahey, A.G.; Gath, V.P.; Molloy, B.P.; Taylor, S.J.; Mulligan, F.J. The effect of calcareous marine algae, with or without marine magnesium oxide, and sodium bicarbonate on rumen $\mathrm{pH}$ and milk production in mid-lactation dairy cows. J. Dairy Sci. 2019, 102, 8027-8039. [CrossRef]

50. Cruywagen, C.W.; Taylor, S.; Beya, M.M.; Calitz, T. The effect of buffering dairy cow diets with limestone, calcareous marine algae, or sodium bicarbonate on ruminal $\mathrm{pH}$ profiles, production responses, and rumen fermentation. J. Dairy Sci. 2015, 98, 5506-5514. [CrossRef]

51. Caroprese, M.; Ciliberti, M.G.; Marino, R.; Santillo, A.; Sevi, A.; Albenzio, M. Polyunsaturated fatty acid supplementation: Effects of seaweed Ascophyllum nodosum and flaxseed on milk production and fatty acid profile of lactating ewes during summer. J. Dairy Res. 2016, 83, 289-297. [CrossRef]

52. Quigley, A.; Walsh, S.W.; Hayes, E.; Connolly, D.; Cummins, W. Effect of seaweed supplementation on tocopherol concentrations in bovine milk using dispersive liquid-liquid microextraction. J. Chromatogr. B Analyt. Technol. Biomed. Life Sci. 2018, 1092, 152-157. [CrossRef]

53. Lee, J.-S.; Kang, S.; Kim, M.-J.; Han, S.-G.; Lee, H.-G. Dietary supplementation with combined extracts from garlic (Allium sativum), brown seaweed (Undaria pinnatifida), and pinecone (Pinus koraiensis) improves milk production in Holstein cows under heat stress conditions. Asian-Australas. J. Anim. Sci. 2020, 33, 111-119. [CrossRef]

54. De Lima, R.N.; de Souza, J.B.F., Jr.; Batista, N.V.; de Andrade, A.K.S.; Soares, E.C.A.; dos Santos Filho, C.A.S.; Silva, L.A.; Coelho, W.A.C.; Costa, L.L.M.; Lima, P.O. Mitigating heat stress in dairy goats with inclusion of seaweed Gracilaria birdiae in diet. Small Rumin. Res. 2019, 171, 87-91. [CrossRef]

55. Kinley, R.D.; de Nys, R.; Vucko, M.J.; Machado, L.; Tomkins, N.W. The red macroalgae Asparagopsis taxiformis is a potent natural antimethanogenic that reduces methane production during in vitro fermentation with rumen fluid. Anim. Prod. Sci. 2016, 56, 282. [CrossRef]

56. Li, X.; Norman, H.C.; Kinley, R.D.; Laurence, M.; Wilmot, M.; Bender, H.; de Nys, R.; Tomkins, N. Asparagopsis taxiformis decreases enteric methane production from sheep. Anim. Prod. Sci. 2018, 58, 681. [CrossRef]

57. Jacob-Lopez, E.; Maroneze, M.M.; Quieroz, M.I.; Zepka, L.Q. Handbook of Microalgae-Based Processes and Products: Fundamentals and Advances in Energy, Food, Feed, Fertilizer, and Bioactive Compounds; Academic Press: Cambridge, MA, USA, 2020; ISBN 978-012-818-5360.

58. Altomonte, I.; Salari, F.; Licitra, R.; Martini, M. Use of microalgae in ruminant nutrition and implications on milk quality-A review. Livest. Sci. 2018, 214, 25-35. [CrossRef]

59. Gouveia, L.; Batista, A.P.; Sousa, I.; Raymundo, A.; Bandarra, N.M. Microalgae in novel food products. In Food Chemistry Research Developments; Papadopoulos, K.N., Ed.; Nova Science Publishers, Inc.: New York, NY, USA, 2008; pp. 75-111, ISBN 978-1-60456-262-0.

60. Kovač, D.J.; Simeunović, J.B.; Babić, O.B.; Mišan, A.Č.; Milovanović, I.L. Algae in food and feed. Food Feed Res. 2013, 40, 21-31.

61. Becker, E.W. Microalgae in human and animal nutrition. In Handbook of Microalgal Culture: Biotechnology and Applied Phycology; Richmond, A., Ed.; Blackwell: Oxford, UK, 2004; pp. 312-351. [CrossRef]

62. Kotrbáček, V.; Doubek, J.; Doucha, J. The chlorococcalean alga Chlorella in animal nutrition: A review. J. Appl. Phycol. 2015, 27, 2173-2180. [CrossRef]

63. Adarme-Vega, T.C.; Lim, D.K.Y.; Timmins, M.; Vernen, F.; Li, Y.; Schenk, P.M. Microalgal biofactories: A promising approach towards sustainable omega-3 fatty acid production. Microb. Cell Fact. 2012, 11, 96. [CrossRef]

64. Xin, Y.; Shen, C.; She, Y.; Chen, H.; Wang, C.; Wei, L.; Yoon, K.; Han, D.; Hu, Q.; Xu, J. Biosynthesis of triacylglycerol molecules with a tailored PUFA profile in industrial microalgae. Mol. Plant. 2019, 12, 474-488. [CrossRef]

65. Patelou, M.; Infante, C.; Dardelle, F.; Randewig, D.; Kouri, E.D.; Udvardi, M.K.; Tsiplakou, E.; Mantecón, L.; Flemetakis, E. Transcriptomic and metabolomic adaptation of Nannochloropsis gaditana grown under different light regimes. Algal Res. 2020, 45, 101735. [CrossRef]

66. Molino, A.; Mehariya, S.; Karatza, D.; Chianese, S.; Iovine, A.; Casella, P.; Marino, T.; Musmarra, D. Bench-scale cultivation of microalgae Scenedesmus almeriensis for $\mathrm{CO}_{2}$ capture and lutein production. Energies 2019, 12, 2806. [CrossRef] 
67. Lamminen, M.; Halmemies-Beauchet-Filleau, A.; Kokkonen, T.; Jaakkola, S.; Vanhatalo, A. Different microalgae species as a substitutive protein feed for soya bean meal in grass silage based dairy cow diets. Anim. Feed Sci. Technol. 2019, 247, 112-126. [CrossRef]

68. Kumar, B.R.; Deviram, G.; Mathimani, T.; Duc, P.A.; Pugazhendhi, A. Microalgae as rich source of polyunsaturated fatty acids. Biocatal. Agric. Biotechnol. 2019, 17, 583-588. [CrossRef]

69. Lum, K.K.; Kim, J.; Lei, X.G. Dual potential of microalgae as a sustainable biofuel feedstock and animal feed. J. Anim. Sci. Biotechnol. 2013, 4, 1-7. [CrossRef]

70. Becker, E.W. Micro-algae as a source of protein. Biotech. Adv. 2007, 25, 207-210. [CrossRef]

71. Spolaore, P.; Joannis-Cassan, C.; Duran, E.; Isambert, A. Commercial applications of microalgae-review. J. Biosci. Bioeng. 2006, 101, 87-96. [CrossRef]

72. Plaza, M.; Herrero, M.; Cifuentes, A.; Ibáñez, E. Innovative natural functional ingredients from microalgae. J. Agric. Food Chem. 2009, 57, 7159-7170. [CrossRef] [PubMed]

73. Holman, B.W.B.; Malau-Aduli, A.E.O. Spirulina as a livestock supplement and animal feed. J. Anim. Physiol. Anim. Nutr. 2013, 97, 615-623. [CrossRef] [PubMed]

74. Han, P.; Li, J.; Zhong, H.; Xie, J.; Zhang, P.; Lu, Q.; Li, J.; Xu, P.; Chen, P.; Leng, L.; et al. Anti-oxidation properties and therapeutic potentials of spirulina. Algal Res. 2021, 55, 102240. [CrossRef]

75. Higuera-Ciapara, I.; Félix-Valenzuela, L.; Goycoolea, F.M. Astaxanthin: A review of its chemistry and applications. Crit. Rev. Food Sci. Nutr. 2006, 46, 185-196. [CrossRef]

76. Sui, Y.; Muys, M.; Van de Waal, D.B.; D'Adamo, S.; Vermeir, P.; Fernandes, T.V.; Vlaeminck, S.E. Enhancement of co-production of nutritional protein and carotenoids in Dunaliella salina using a two-phase cultivation assisted by nitrogen level and light intensity. Bioresour. Technol. 2019, 287. [CrossRef]

77. Gagliostro, G.A.; Antonacci, L.E.; Pérez, C.D.; Rossetti, L.; Carabajal, A. Improving the quality of milk fatty acid in dairy cows supplemented with soybean oil and DHA-micro algae in a confined production system. Agric. Sci. 2018, 9, 1115-1130. [CrossRef]

78. Lock, A.L.; Bauman, D.E. Modifying milk fat composition of dairy cows to enhance fatty acids beneficial to human health. Lipids 2004, 39, 1197-1206. [CrossRef]

79. Glover, K.E.; Budge, S.; Rose, M.; Rupasinghe, H.P.V.; MacLaren, L.; Green-Johnson, J.; Fredeen, A.H. Effect of feeding fresh forage and marine algae on the fatty acid composition and oxidation of milk and butter. J. Dairy Sci. 2012, 95, 2797-2809. [CrossRef]

80. Kouřimská, L.; Vondráčková, E.; Fantová, M.; Nový, P.; Nohejlová, L.; Michnová, K. Effect of feeding with algae on fatty acid profile of goat's milk. Sci. Agric. Bohem. 2014, 45, 162-169. [CrossRef]

81. Chilliard, Y.; Glasser, F.; Ferlay, A.; Bernard, L.; Rouel, J.; Doreau, M. Diet, rumen biohydrogenation and nutritional quality of cow and goat milk fat. Eur. J. Lipid Sci. Technol. 2007, 109, 828-855. [CrossRef]

82. Jenkins, T.J.; Bridges, W.C. Protection of fatty acids against ruminal biohydrogenation in cattle. Eur. J. Lipid Sci. 2007, 109, 778-779. [CrossRef]

83. Kitessa, S.M.; Gulati, S.K.; Ashes, J.R.; Fleck, E.; Scott, T.W.; Nichols, P.D. Utilisation of fish oil in ruminants. II. Transfer of fish oil fatty acids into goat's milk. Anim. Feed Sci. Technol. 2001, 89, 201-208. [CrossRef]

84. Marques, J.A.; Del Valle, T.A.; Ghizzi, L.G.; Zilio, E.M.C.; Gheller, L.S.; Nunes, A.T.; Silva, T.B.P.; Dias, M.S.D.S.; Grigoletto, N.T.S.; Koontz, A.F.; et al. Increasing dietary levels of docosahexaenoic acid-rich microalgae: Ruminal fermentation, animal performance, and milk fatty acid profile of mid-lactating dairy cows. J. Dairy Sci. 2019, 102, 5054-5065. [CrossRef] [PubMed]

85. Liu, G.; Yu, X.; Li, S.; Shao, W.; Zhang, N. Effects of dietary microalgae (Schizochytrium spp.) supplement on milk performance, blood parameters, and milk fatty acid composition in dairy cows. Czech J. Anim. Sci. 2020, 65, 162-171. [CrossRef]

86. Moate, P.J.; Williams, S.R.O.; Hannah, M.C.; Eckard, R.J.; Auldist, M.J.; Ribaux, B.E.; Jacobs, J.L.; Wales, W.J. Effects of feeding algal meal high in docosahexaenoic acid on feed intake, milk production, and methane emissions in dairy cows. J. Dairy Sci. 2013, 96, 3177-3188. [CrossRef]

87. Reynolds, C.K.; Cannon, V.L.; Loerch, S.C. Effects of forage source and supplementation with soybean and marine algal oil on milk fatty acid composition of ewes. Anim. Feed Sci. Technol. 2006, 131, 333-357. [CrossRef]

88. Toral, P.G.; Hervás, G.; Gómez-Cortés, P.; Frutos, P.; Juárez, M.; de la Fuente, M.A. Milk fatty acid profile and dairy sheep performance in response to diet supplementation with sunflower oil plus incremental levels of marine algae. J. Dairy Sci. 2010, 93, 1655-1667. [CrossRef]

89. Bichi, E.; Hervás, G.; Toral, P.G.; Loor, J.J.; Frutos, P. Milk fat depression induced by dietary marine algae in dairy ewes: Persistency of milk fatty acid composition and animal performance responses. J. Dairy Sci. 2013, 96, 524-532. [CrossRef] [PubMed]

90. Noike, T.; Ko, I.B.; Yokoyama, S.; Kohno, Y.; Li, Y.Y. Continuous hydrogen production from organic waste. Water Sci. Technol. 2005, 52, 145-151. [CrossRef] [PubMed]

91. Li, S.; Zhu, D.; Li, K.; Yang, Y.; Lei, Z.; Zhang, Z. Soybean curd residue: Utilization, and related limiting factors. IRSN Ind. Eng. 2013, 64, 968-973. [CrossRef]

92. Redondo-Cuenca, A.; Villanueva-Suarez, M.J.; Mateos-Aparicio, I. Soybean seeds and its by-product okara as sources of dietary fibre. Measurement by AOAC and Englyst methods. Food Chem. 2008, 108, 1099-1105. [CrossRef] [PubMed]

93. Rinaldi, V.E.A.; Ng, P.K.W.; Bennink, M.R. Effects of extrusion on dietary fiber and isoflavone contents of wheat extrudets enriched with wet okara. Cereal Chem. 2000, 77, 237-240. [CrossRef] 
94. Motawe, H.F.A.P.; El Shinnawy, A.M.; El Afifi, T.M.; Hashem, N.A.; Abu Zaid, A.A.M. Utilization of okara meal as a source of plant protein in broiler diets. J. Anim. Poult. Prod. Mansoura Univ. 2012, 3, 127-136. [CrossRef]

95. Almaraz, J.J.; Zhou, X.M.; Mabood, F.; Mandramootoo, C.; Rochette, P.; Mao, B.-L.; Smith, D.L. Greenhouse gas fluxes associated with soybean production under two tillage systems in Southwestern Quebec. Soil Till. Res. 2009, 104, 134-139. [CrossRef]

96. Cuadros, F.; López-Rodríguez, F.; Ruiz-Celma, A.; Rubiales, F.; González-González, A. Recycling, reuse and energetic valuation of meat industry wastes in Extremadura (Spain). Resour. Conserv. Recy. 2011, 55, 393-399. [CrossRef]

97. Song, C.; Kitamura, Y.; Li, S.; Ogasawara, K. Design of a cryogenic $\mathrm{CO}_{2}$ capture system based on Stirling coolers. Int. J. Greenh . Gas Contr. 2012, 7, 107-114. [CrossRef]

98. Cheng, Y.; Shimizu, N.; Kimura, T. The viscoelastic properties of soybean curd (tofu) as affected by soymilk concentration and type of coagulant. Inter. J. Food Sci. Technol. 2005, 40, 385-390. [CrossRef]

99. Zang, Y.; Santana, R.A.V.; Moura, D.C.; Galväo, J.G.B., Jr.; Brito, A.F. Replacing soybean meal with okara meal: Effects on production, milk fatty acid and plasma amino acid profile, and nutrient utilization in dairy cows. J. Dairy Sci. 2020, 104. [CrossRef]

100. Quitain, A.T.; Oro, K.; Katoh, S.; Moriyoshi, T. Recovery of oil components of okara by ethanol-modified supercritical carbon dioxide extraction. Bioresour. Technol. 2006, 97, 1509-1514. [CrossRef] [PubMed]

101. Vahvaselkä, M.; Laakso, S. Production of cis-9, trans11-conjugated linoleic acid in camelina meal and okara by an oat-assisted microbial process. J. Agric. Food Chem. 2010, 58, 2479-2482. [CrossRef] [PubMed]

102. Brossillon, V.; Reis, S.F.; Moura, D.C.; Galvão, J.G.B., Jr.; Oliveira, A.S.; Côrtes, C.; Brito, A.F. Production, milk and plasma fatty acid profile, and nutrient utilization in Jersey cows fed flaxseed oil and corn grain with different particle size. J. Dairy Sci. 2018, 101, 2127-2143. [CrossRef]

103. Kim, K.H.; Kim, S.J.; Jeon, B.T.; Kim, D.H.; Oh, M.R.; Park, P.J.; Kweon, H.J.; Oh, B.Y.; Hur, S.J.; Moon, S.H. Effects of dietary soybean curd residue on the growth performance and carcass characteristics in Hanwoo (Bos taurus coreanae) steer. Afr. J. Agric. Res. 2012, 7, 4331-4336. [CrossRef]

104. Rahman, M.M.; Nakagawa, T.; Abdullah, R.B.; Embong, W.K.W.; Akashi, R. Feed intake and growth performance of goats supplemented with soy waste. Pesqui. Agropecu. Bras. 2014, 49, 554-558. [CrossRef]

105. Rahman, M.M.; Rahman, M.R.; Nakagawa, T.; Abdullah, R.B.; Khadijah, W.E.W.; Akashi, R. Effects of wet soya waste supplementation on the intake, growth and reproduction of goats fed Napier grass. Anim. Feed Sci. Technol. 2015, 199, 104-112. [CrossRef]

106. Harthan, L.B.; Cherney, D.J.R. Okara as a protein supplement affects feed intake and milk composition of ewes and growth performance of lambs. Anim. Nutr. 2017, 3, 171-174. [CrossRef]

107. Eliyahu, D.; Yosef, E.; Weinberg, Z.G.; Hen, Y.; Nikbachat, M.; Solomon, R.; Mabjeesh, S.J.; Miron, J. Composition, preservation and digestibility by sheep of wet by-products from the food industry. Anim. Feed Sci. Technol. 2015, 207, 1-9. [CrossRef]

108. Woods, V.B.; Fearon, A.N. Dietary sources of unsaturated fatty acids for animals and their transfer into meat, milk and eggs: A review. Livest. Sci. 2009, 126, 1-20. [CrossRef]

109. Hurtaud, C.; Peyraud, J.L. Effects of feeding camelina (seeds or meal) on milk fatty acids composition and butter spreadability. J. Dairy Sci. 2007, 90, 5134-5145. [CrossRef] [PubMed]

110. Bernard, L.; Bonnet, M.; Delavaud, C.; Delosiere, M.; Ferlay, A.; Fougere, H.; Graulet, B. Milk fat globule in ruminant: Major and minor compounds, nutritional regulation and differences among species. Eur. J. Lipid Sci. Technol. 2018, 120, 1700039. [CrossRef]

111. Rodríguez-Rodríguez, M.F.; Sánchez-García, A.; Salas, J.J.; Garcés, R.; Martínez-Force, E. Characterization of the morphological changes and fatty acid profile of developing Camelina sativa seeds. Ind. Crop. Prod. 2013, 20, 673-679. [CrossRef]

112. Moser, B. Camelina (Camelina sativa L.) oil as a biofuels feedstock: Golden opportunity or false hope? Lipid Technol. 2010, 22, 270-273. [CrossRef]

113. Fröhlich, A.; Rice, B. Evaluation of Camelina sativa oil as a feedstock for biodiesel production. Ind. Crop. Prod. 2005, 21, 25-31. [CrossRef]

114. Zubr, J. Qualitative variation of Camelina sativa seed from different locations. Ind. Crop. Prod. 2003, 17, 161-169. [CrossRef]

115. Vollmann, J.; Moritz, T.; Kargl, C.; Baumgartner, S.; Wagentristl, H. Agronomic evaluation of Camelina genotypes selected for seed quality characteristics. Ind. Crop. Prod. 2007, 26, 270-277. [CrossRef]

116. Bansal, S.; Durrett, T.P. Camelina sativa: An ideal platform for the metabolic engineering and field production of industrial lipids. Biochimie 2016, 120, 9-16. [CrossRef]

117. Sarramonne, J.P.; Gervais, R.; Benchaar, C.; Chouinard, P.Y. Lactation performance and milk fatty acid composition of lactating dairy cows fed Camelina sativa seeds or expeller. Anim. Feed Sci. Technol. 2020, 270, 114697. [CrossRef]

118. Russo, R.; Reggiani, R. Glucosinolates and sinapine in camelina meal. Food Nutr. Sci. 2017, 8, 1063-1073. [CrossRef]

119. Halmemies-Beauchet-Filleau, A.; Kokkonen, T.; Lampi, A.M.; Toivonen, V.; Shingfield, K.J.; Vanhatalo, A. Effect of plant oils and camelina expeller on milk fatty acid composition in lactating cows fed diets based on red clover silage. J. Dairy Sci. 2011, 94, 4413-4430. [CrossRef]

120. Mihhejev, K.; Henno, M.; Ots, M.; Rihma, E.; Elias, P.; Kuusik, S.; Kärt, O. Effects of fat-rich oil cakes on cheese fatty acid composition, and on cheese quality. Vet. Zootec. 2007, 40, 55-61. 
121. Pikul, J.; Wojtowski, J.; Dankow, R.; Teichert, J.; Czyzak-Runowska, G.; Cais-Sokolinska, D.; Cieslak, A.; Szumacher-Strabel, M.; Bagnicka, E. The effect of false flax (Camelina sativa) cake dietary supplementation in dairy goats on fatty acid profile of kefir. Small Rumin. Res. 2014, 122, 44-49. [CrossRef]

122. Szumacher-Strabel, M.; Cieślak, A.; Zmora, P.; Pers-Kamczyc, E.; Bielinska, S.; Stanisz, M.; Wojtowski, J. Camelina sativa cake improved unsaturated fatty acids in ewe's milk. J. Sci. Food Agric. 2011, 91, 2031-2037. [CrossRef]

123. Halmemies-Beauchet-Filleau, A.; Shingfield, K.J.; Simpura, I.; Kokkonen, T.; Jaakkola, S.; Toivonen, V.; Vanhatalo, A. Effect of incremental amounts of camelina oil on milk fatty acid composition in lactating cows fed diets based on a mixture of grass and red clover silage and concentrates containing camelina expeller. J. Dairy Sci. 2017, 100, 305-324. [CrossRef]

124. Willcox, J.K.; Ash, S.L.; Catignani, G.L. Antioxidants and prevention of chronic disease. Crit. Rev. Food Sci. Nutr. 2004, 44, 275-295. [CrossRef]

125. Alenisan, M.A.; Alqattan, H.H.; Tolbah, L.S.; Shori, A.B. Antioxidant properties of dairy products fortified with natural additives: A review. J. Assn. Arab. Univ. Basic Appl. Sci. 2017, 24, 101-106. [CrossRef]

126. Vuazour, D.; Rodriguez-Mateous, A.; Corona, G.; Oruna-Concha, M.J.; Spencer, J.P.E. Polyphenols and human health: Prevention of disease and mechanisms of action. Nutrients 2010, 2, 1106-1131. [CrossRef] [PubMed]

127. Chedea, V.S.; Pelmus, R.S.; Cismileanu, A.E.; Pistol, G.C.; Palade, L.M.; Taranu, I. Total polyphenols content, antioxidant activity and stability of a grape pomace incorporated in animal feed. Anim. Sci. Biotech. 2016, 49, 1-5.

128. Khiaosa-ard, R.; Metzler-Zebeli, B.U.; Ahmed, S.; Muro-Reyes, A.; Deckardt, K.; Chizzola, R.; Böhm, J.; Zebeli, Q. Fortification of dried distillers grains plus solubles with grape seed meal in the diet modulates methane mitigation and rumen microbiota in Rusitec. J. Dairy Sci. 2015, 98, 2611-2626. [CrossRef]

129. Ragni, M.; Vicenti, A.; Melodia, L.; Marsico, G. Use of grape seed flour in feed for lambs and effects on performance and meat quality. APCBEE Procedia 2014, 8, 59-64. [CrossRef]

130. Nudda, A.; Correddu, F.; Marzano, A.; Battacone, G.; Nicolussi, P.; Bonelli, P.; Pulina, G. Effects of diets containing grape seed, linseed, or both on milk production traits, liver and kidney activities, and immunity of lactating dairy ewes. J. Dairy Sci. 2015, 98, 1157-1166. [CrossRef] [PubMed]

131. Correddu, F.; Gaspa, G.; Pulina, G.; Nudda, A. Grape seed and linseed, alone and in combination, enhance unsaturated fatty acids in the milk of Sarda dairy sheep. J. Dairy Sci. 2016, 9, 1725-1735. [CrossRef]

132. Correddu, F.; Nudda, A.; Manca, M.G.; Pulina, G.; Dalsgaard, T.K. Light-induced lipid oxidation in sheep milk: Effects of dietary grape seed and linseed, alone or in combination, on milk oxidative stability. J. Agric. Food Chem. 2015, 63, 3980-3986. [CrossRef] [PubMed]

133. Palmquist, D.R.; Jenkins, T.C. A 100-year review: Fat feeding of dairy cows. J. Dairy Sci. 2017, 100, 10061-10077. [CrossRef] [PubMed]

134. Majewska, P.; Kowalik, B. Growth performance, carcass characteristics, fatty acid composition, and blood biochemical parameters of lamb fed diet with the addition of lingonberry leaves and oak bark. Eur. J. Lipid Sci. Technol. 2020, 122, 1900273. [CrossRef]

135. Vasta, V.; Daghio, M.; Cappucci, A.; Buccioni, A.; Serra, A.; Vitti, C.; Mele, M. Invited review: Plant polyphenols and rumen microbiota responsible for fatty acid biohydrogenation, fiber digestion, and methane emission: Experimental evidence and methodological approaches. J. Dairy Sci. 2019, 102, 3781-3804. [CrossRef]

136. Morales, R.; Ungerfeld, E.M. Use of tannins to improve fatty acids profile of meat and milk quality in ruminants: A review. Chil. J. Agric. Res. 2015, 75, 239-248. [CrossRef]

137. Frutos, P.; Hervás, G.; Giráldez, F.J.; Mantecón, A.R. Tannins and ruminant nutrition. Span. J. Agric. Res. 2004, 2, 191-202. [CrossRef]

138. Vasta, V.; Mele, M.; Serra, A.; Scerra, M.; Luciano, G.; Lanza, M.; Priolo, A. Metabolic fate of fatty acids involved in ruminal biohydrogenation in sheep fed concentrate or herbage with or without tannins. J. Anim. Sci. 2009, 87, 2674-2684. [CrossRef]

139. Focant, M.; Froidmont, E.; Archambeau, Q.; Dang Van, Q.C.; Larondelle, Y. The effect of oak tannin (Quercus robur) and hops (Humulus lupulus) on dietary nitrogen efficiency, methane emission, and milk fatty acid composition of dairy cows fed a low-protein diet including linseed. J. Dairy Sci. 2019, 102, 1-16. [CrossRef]

140. Bhatta, R.; Uyeno, Y.; Tajima, K.; Takenaka, A.; Yabumoto, Y.; Nonaka, I.; Enishi, O.; Kurihara, M. Difference in the nature of tannins on in vitroC ruminal methane and volatile fatty acid production and on methanogenic archaea and protozoal populations. J. Dairy Sci. 2009, 92, 5512-5522. [CrossRef]

141. Patra, A.K.; Saxena, J. Exploitation of dietary tannins to improve rumen metabolism and ruminant nutrition. J. Sci. Food Agric. 2011, 91, 24-37. [CrossRef] [PubMed]

142. Jayanegara, A.; Leiber, F.; Kreuzer, M. Meta-analysis of the relationship between dietary tannin level and methane formation in ruminants from in vivo and in vitro experiments. J. Anim. Physiol. Anim. Nutr. 2012, 96, 365-375. [CrossRef] [PubMed]

143. Benchaar, C.; Greathead, H. Essential oils and opportunities to mitigate enteric methane emissions from ruminants. Anim. Feed Sci. Technol. 2011, 166, 338-355. [CrossRef]

144. Bosabalidis, A.M. Structural features of Origanum sp. In Medicinal and Aromatic Plants—Industrial Profiles, Oregano. The Genera Origanum and Lippia; Kintzios, S.E., Ed.; Taylor \& Francis: London, UK; New York, NY, USA, 2002; pp. 11-64.

145. Horky, P.; Skalickova, S.; Smerkova, K.; Skladanka, J. Essential oils as a feed additives: Pharmacokinetics and potential toxicity in monogastric animals. Animals 2019, 9, 352. [CrossRef] [PubMed] 
146. Veres, K.; Varga, E.; Dobos, Á.; Hajdú, Z.; Máthé, I.; Németh, É.; Szabó, K. Investigation of the composition and stability of the essential oils of Origanum vulgare ssp. vulgare L. and O. vulgare ssp. hirtum (Link) Ietswaart. Chromatographia 2011, 57, 95-98. [CrossRef]

147. Lukas, B.; Schmiderer, C.; Novak, J. Essential oil diversity of European Origanum vulgare L. (Lamiaceae). Phytochemistry 2015, 119, 32-40. [CrossRef]

148. Olijhoek, D.W.; Hellwing, A.L.F.; Grevsen, K.; Haveman, L.S.; Chowdhury, M.R.; Løvendahl, P.; Weisbjerg, M.R.; Noel, S.L.; Højberg, O.; Wiking, L.; et al. Effect of dried oregano (Origanum vulgare L.) plant material in feed on methane production, rumen fermentation, nutrient digestibility, and milk fatty acid composition in dairy cows. J. Dairy Sci. 2019, 102, 9902-9918. [CrossRef]

149. Tekippe, J.A.; Hristov, A.N.; Heyler, K.S.; Cassidy, T.W.; Zheljazkov, V.D.; Ferreira, J.F.S.; Karnati, S.K.; Varga, G.A. Rumen fermentation and production effects of Origanum vulgare L. leaves in lactating dairy cows. J. Dairy Sci. 2011, 94, 5065-5079. [CrossRef]

150. Lejonklev, J.; Kidmose, U.; Jensen, S.; Petersen, M.A.; Hellwing, A.L.F.; Mortensen, G.; Weisbjerg, M.R.; Larsen, M.K. Effect of oregano and caraway essential oils on the production and flavor of cow milk. J. Dairy Sci. 2016, 99, 7898-7903. [CrossRef] [PubMed]

151. Hristov, A.N.; Lee, C.; Cassidy, T.T.; Heyler, K.; Tekippe, J.A.; Varga, G.A.; Corl, B.; Brandt, R.C. Effect of Origanum vulgare L. leaves on rumen fermentation, production, and milk fatty acid composition in lactating dairy cows. J. Dairy Sci. 2013, 96, 1189-1202. [CrossRef] [PubMed]

152. Kolling, G.J.; Stivanin, S.C.B.; Gabbi, A.M.; Machado, F.S.; Ferreira, A.L.; Campos, M.M.; Tomich, T.R.; Cunha, C.S.; Dill, S.W.; Pereira, L.G.R.; et al. Performance and methane emissions in dairy cows fed oregano and green tea extracts as feed additives. J. Dairy Sci. 2018, 101, 4221-4234. [CrossRef] [PubMed]

153. Calsamiglia, S.; Busquet, M.; Cardozo, P.W.; Castillejos, L.; Ferret, A. Invited review: Essential oils as modifiers of rumen microbial fermentation. J. Dairy Sci. 2007, 90, 2580-2595. [CrossRef] [PubMed]

154. Lavrenčič, A.; Levart, A.; Košir, I.J.; Čerenak, A. Influence of two hop (Humulus lupulus L.) varieties on in vitro dry matter and crude protein degradability and digestibility in ruminants. J. Sci. Food Agric. 2014, 94, 1248-1252. [CrossRef]

155. Narvaez, N.; Wang, Y.; Xu, Z.; Alexander, T.; Garden, S.; McAllister, T. Effects of hop varieties on ruminal fermentation and bacterial community in an artificial rumen (rusitec). J. Sci. Food Agric. 2013, 93, 45-52. [CrossRef]

156. Dang Van, Q.C.; Bejarano, L.; Mignolet, E.; Coulmier, D.; Froidmont, E.; Larondelle, Y.; Focant, M. Effectiveness of extruded rapeseed associated with an alfalfa protein concentrate in enhancing the bovine milk fatty acid composition. J. Dairy Sci. 2011, 94, 4005-4015. [CrossRef]

157. Nefzaoui, A.; Ben Salem, H. Forage, fodder, and animal nutrition. In Cacti: Biology and Uses; Nobel, P.S., Ed.; University of California Press Ltd.: Oakland, CA, USA, 2002; pp. 199-210.

158. Sá, W.C.C.S.; Santos, E.M.; Oliveira, J.S.; Perazzo, A.F. Production of spineless cactus in brazilian semiarid. In New Perspectives in Forage Crops; Edvan, R.L., Bezerra, L.R., Eds.; IntechOpen: London, UK, 2018; pp. 25-50. [CrossRef]

159. Ferreira, M.A.; Bispo, S.V.; Filho, R.R.R.; Urbano, S.A.; Costa, C.T.F. The use of cactus as forage for dairy cows in semi-arid regions of Brazil. In Organic Farming and Food Production; Konvalina, P., Ed.; IntechOpen: London, UK, 2012; pp. 169-189. [CrossRef]

160. Gama, M.A.S.; de Paula, T.A.; Véras, A.S.C.; Guido, S.I.; Borges, C.A.V.; Antoniassi, R.; Lopes, F.C.F.; Neves, M.L.M.W.; Ferreira, M.D.A. Partially replacing sorghum silage with cactus (Opuntia stricta) cladodes in a soybean oil-supplemented diet markedly increases trans-11 18:1, cis-9, trans-11 CLA and 18:2 n-6 contents in cow milk. J. Anim. Physiol. Anim. Nutr. 2021, 105, 232-246. [CrossRef]

161. Freitas, W.R.; Gama, M.A.S.; Silva, J.L.; Véras, A.S.C.; Chagas, J.C.C.; Conceição, M.G.; Almeida, G.A.P.; Calsavara, A.F.; Alves, A.M.S.V.; Ferreira, M.A.F. Milk fatty acid profile of dairy cows fed diets based on sugarcane bagasse in the Brazilian region. Chil. J. Agric. Res. 2019, 79, 464-472. [CrossRef]

162. Souza, S.M.; Lopes, F.C.F.; Valadares Filho, S.C.; Gama, M.A.S.; Rennó, L.N.; Rodrigues, J.P.P. Milk fatty acid composition of Holstein x Gyr dairy cows fed sugarcane-based diets containing citrus pulp supplemented with sunflower oil. Semina: Ciências Agrárias 2019, 40, 1663-1680. [CrossRef]

163. Qiu, X.; Eastridge, M.L.; Firkins, J.L. Effects of dry matter intake, addition of buffer, and source of fat on duodenal flow and concentration of conjugated linoleic acid and trans-11 C18:1 in milk. J. Dairy Sci. 2004, 87, 4278-4286. [CrossRef]

164. Astello-García, M.G.; Cervantes, I.; Nair, V.; Santos-Díaz, M.; ReyesAgüero, A.; Guéraud, F.; Negre-Salvayre, A.; Rossignol, M.; Cisneros Zevallos, L.; Barba de La Rosa, A.P. Chemical composition and phenolic compounds profile of cladodes from Opuntia spp. cultivars with different domestication gradient. J. Food Compos. Anal. 2015, 43, 119-130. [CrossRef]

165. Bakari, S.; Daoud, A.; Felhi, S.; Smaoui, S.; Gharsallah, N.; Kadri, A. Proximate analysis, mineral composition, phytochemical contents, antioxidant and antimicrobial activities and GC-MS investigation of various solvent extracts of cactus cladode. Food Sci. Technol. 2017, 37, 286-293. [CrossRef]

166. Alves, F.A.L.; Andrade, A.P.; Bruno, R.L.A.; Silva, M.G.V.; Souza, M.F.V.; Santos, D.C. Seasonal variability of phenolic compounds and antioxidant activity in prickly pear cladodes of Opuntia and Nopalea genres. Food Sci. Technol. 2018, 37, 536-543. [CrossRef]

167. Izuegbuna, O.; Otunola, G.; Bradley, G. Chemical composition, antioxidant, antiinflammatory, and cytotoxic activities of opuntia stricta cladodes. PLoS ONE 2019, 14, e0209682. [CrossRef] [PubMed] 
168. Bryszak, M.; Szumacher-Strabel, M.; Huang, H.; Pawlak, P.; Lechniak, D.; Kołodziejski, P.; Yanza, Y.R.; Patra, A.K.; Váradyová, Z.; Cieslak, A. Lupinus angustifolius seed meal supplemented to dairy cow diet improves fatty acid composition in milk and mitigates methane production. Anim. Feed Sci. Technol. 2020, 267, 114590. [CrossRef]

169. Monteiro, M.R.P.; Costa, A.B.P.; Campos, S.F.; Silva, M.R.; Silva, C.O.; Martino, H.S.D.; Silvestre, M.P.C. Evaluation of the chemical composition, protein quality and digestibility of lupin (Lupinus albus and Lupinus angustifolius). O Mundo Saúde 2014, 38, 251. [CrossRef]

170. Bähr, M.; Fechner, A.; Hasenkopf, K.; Mittermaier, S.; Jahreis, G. Chemical composition of dehulled seeds of selected lupine cultivars in comparison to pea and soya bean. LWT Food Sci. Technol. Res. 2014, 59, 587. [CrossRef]

171. Księżak, J.; Staniak, M.; Bojarszczuk, J. Nutrient contents in yellow lupine (Lupinus luteus L.) and blue lupine (Lupinus angustifolius L.) cultivars depending on habitat conditions. J. Environ. Stud. 2018, 27, 1145-1153. [CrossRef]

172. Masucci, F.; Di Francia, A.; Romano, R.; di Serracapriola, M.M.; Lambiase, G.; Varricchio, M.L.; Proto, V. Effect of Lupinus albus as protein supplement on yield, constituents, clotting properties and fatty acid composition in ewes' milk. Small Rumin. Res. 2006, 65, 251-259. [CrossRef]

173. Staerfl, S.M.; Amelchanka, S.L.; Kälber, T.; Soliva, C.R.; Kreuzer, M.; Zeitz, J.O. Effect of feeding dried high-sugar ryegrass ('AberMagic') on methane and urinary nitrogen emissions of primiparous cows. Livest. Sci. 2012, 150, 293-301. [CrossRef]

174. Innosa, D.; Ianni, A.; Faccia, M.; Martino, C.; Grotta, L.; Saletti, M.A.; Pomilio, F.; Martino, G. Physical, nutritional, and sensory properties of cheese obtained from goats fed a dietary supplementation with olive leaves. Animals 2020, 10, 2238. [CrossRef]

175. Özcan, M.M.; Matthäus, B. A review: Benefit and bioactive properties of olive (Olea europaea L.) leaves. Eur. Food Res. Technol. 2017, 243, 89-99. [CrossRef]

176. Taamalli, A.; Arráez-Román, D.; Barrajón-Catalán, E.; Ruiz-Torres, V.; Pérez-Sánchez, A.; Herrero, M.; Ibañez, E.; Micol, V.; Zarrouk, M.; Segura-Carretero, A.; et al. Use of advanced techniques for the extraction of phenolic compounds from Tunisian olive leaves: Phenolic composition and cytotoxicity against human breast cancer cells. Food Chem. Toxicol. 2012, 50, 1817-1825. [CrossRef]

177. Lama-Muñoz, A.; del Mar Contreras, M.; Espínola, F.; Moya, M.; Romero, I.; Castro, E. Content of phenolic compounds and mannitol in olive leaves extracts from six Spanish cultivars: Extraction with the Soxhlet method and pressurized liquids. Food Chem. 2020, 320, 1-9. [CrossRef]

178. Aboamer, A.A.; Hend, A.A.; Azzaz, H.H.; Alzahar, H.; Murad, H.A. Impact of urea-treated olive trees by-products on Barki Ewe's nutrients digestibility and milk productivity. Egypt. J. Nutr. Feeds. 2018, 21, 613-623. [CrossRef]

179. Talhaoui, N.; Vezza, T.; Gómez-Caravaca, A.M.; Fernández-Gutiérrez, A.; Gálvez, J.; Segura-Carretero, A. Phenolic compounds and in vitro immunomodulatory properties of three Andalusian olive leaf extracts. J. Funct. Foods. 2016, 22, 270-277. [CrossRef]

180. Şahin, S.; Bilgin, M. A review: Olive tree (Olea europaea L.) leaf as a waste by-product of table olive and olive oil industry. J. Sci. Food Agric. 2017, 98, 1271-1279. [CrossRef]

181. Rahmanian, N.; Jafari, S.M.; Wani, T.A. Bioactive profile, dehydration, extraction and application of the bioactive components of olive leaves. Trends Food Sci. Technol. 2015, 42, 150-172. [CrossRef]

182. Souilem, S.; Fki, I.; Kobayashi, I.; Khalid, N.; Neves, M.A.; Isoda, H.; Sayadi, S.; Nakajima, M. Emerging technologies for recovery of value-added components from olive leaves and their applications in food/feed industries. Food Bioprocess. Technol. 2017, 10, 229-248. [CrossRef]

183. Birkinshaw, A.; Schwarm, A.; Marquardt, S.; Kreuzer, M.; Terranova, M. Rapid responses in bovine milk fatty acid composition and phenol content to various tanniferous forages. J. Anim. Feed Sci. 2020, 29, 297-305. [CrossRef]

184. Johnson, K.A.; Johnson, D.E. Methane emissions from cattle. J. Anim. Sci. 1995, 73, 2483-2492. [CrossRef]

185. Vahmani, P.; Fredeen, A.H.; Glover, K.E. Effect of supplementation with fish oil or microalgae on fatty acid composition of milk from cows managed in confinement or pasture systems. J. Dairy Sci. 2013, 96, 6660-6670. [CrossRef]

186. Moran, C.A.; Morlacchini, M.; Keegan, J.D.; Fusconi, G. The effect of dietary supplementation with Aurantiochytrium limacinum on lactating dairy cows in terms of animal health, productivity and milk composition. J. Anim. Physiol. Anim. Nutr. 2018, 102, 576-590. [CrossRef]

187. Boeckaert, C.; Vlaeminck, B.; Dijkstra, J.; Issa-Zacharia, A.; Van Nespen, T.; Van Straalen, W.; Fievez, V. Effect of dietary starch or micro algae supplementation on rumen fermentation and milk fatty acid composition of dairy cows. J. Dairy Sci. 2008, 91, 4714-4727. [CrossRef]

188. Antaya, N.T.; Soder, K.J.; Kraft, J.; Whitehouse, N.L.; Guindon, N.E.; Erickson, P.S.; Conroy, A.B.; Brito, A.F. Incremental amounts of Ascophyllum nodosum meal do not improve animal performance but do increase milk iodine output in early lactation dairy cows fed high-forage diets. J. Dairy Sci. 2015, 98, 1991-2004. [CrossRef]

189. Pajor, F.; Egerszegi, I.; Szúcs, Á.; Póti, P.; Bodnár, Á. Effect of marine algae supplementation on somatic cell count, prevalence of udder pathogens, and fatty acid profile of dairy goats' milk. Animals 2021, 11, 1097. [CrossRef] [PubMed]

190. Mavrommatis, A.; Sotirakoglou, K.; Skliros, D.; Flemetakis, E.; Tsiplakou, E. Dose and time response of dietary supplementation with Schizochytrium sp. on the abundances of several microorganisms in the rumen liquid of dairy goats. Livest. Sci. 2021, 247, 104489. [CrossRef]

191. Soyeurt, H.; Dehareng, F.; Mayeres, P.; Bertozzi, C.; Gengler, N. Variation of delta (9)-desaturase activity in dairy cattle. J. Dairy Sci. 2008, 91, 3211-3224. [CrossRef] 
192. Lock, A.L.; Garnsworthy, P.C. Seasonal variation in milk conjugated linoleic acid and Delta(9)-desaturase activity in dairy cows. Livest. Prod. Sci. 2003, 79, 47-59. [CrossRef]

193. Moran, C.; Morlacchini, M.; Fusconi, G. Enhancing the DHA content in milk from dairy cows by feeding ALL-G-RICH ${ }^{\mathrm{TM}}$. J. Appl. Anim. Nutr. 2017, 5, 1-9. [CrossRef]

194. Fougère, H.; Delavaud, C.; Bernard, L. Diets supplemented with starch and corn oil, marine algae, or hydrogenated palm oil differentially modulate milk fat secretion and composition in cows and goats: A comparative study. J. Dairy Sci. 2018, 101, 8429-8445. [CrossRef] 